\title{
Consumer Brand Engagement in Social Media: Conceptualization, Scale Development \& Validation
}

\begin{abstract}
In the last three decades an influential research stream has emerged, which highlights the dynamics of focal consumer/brand relationships. Specifically, more recently the 'consumer brand engagement' (CBE) concept has been postulated to more comprehensively reflect the nature of consumers' particular interactive brand relationships, relative to traditional concepts, including 'involvement.' However, despite the growing scholarly interest regarding the undertaking of marketing research addressing 'engagement,' studies have been predominantly exploratory in nature; thus generating a lack of empirical research in this area to date. By developing and validating a CBE scale in specific social media settings, we address this identified literature gap. Specifically, we conceptualize CBE as a consumer's positively valenced brand-related cognitive, emotional and behavioral activity during or related to focal consumer/brand interactions. We derive three $\mathrm{CBE}$ dimensions, including cognitive processing, affection, and activation. Within three different social media contexts, we employ exploratory and confirmatory factor analyses to develop a reliable, 10-item CBE scale, which we proceed to validate within a nomological net of conceptual relationships and a rival model. The findings suggest that while consumer brand 'involvement' acts as a CBE antecedent, consumer 'self-brand connection' and 'brand usage intent' represent key CBE consequences; thus providing a platform for further research in this emerging area. We conclude with an overview of key managerial and scholarly implications arising from this research.
\end{abstract}

Keywords: Consumer brand engagement, social media, scale development, structural equation modeling 


\section{Introduction}

In the last three decades a powerful research stream has emerged, which highlights the nature and dynamics pertaining to specific consumer/brand relationships (Fournier 1998; Aaker, Fournier and Brasel 2004). Within this emerging body of work, consumer brand 'involvement,' which reflects a consumer's level of interest in, and personal relevance of a brand, has gained significant attention (Zaichkowsky 1985, 1994; Coulter et al. 2003). However, despite the important insights gleaned from 'involvement' research, more recently scholarly emphasis is shifting to concepts and theoretical perspectives, which explain or predict the dynamics characterizing focal interactive consumer/brand relationships more explicitly, including in specific social media settings (Malthouse and Hofacker 2010; Bolton and Saxena-Iyer 2009).

Within this broader context, the consumer 'engagement' concept, which more explicitly accounts for consumers' interactive brand-related dynamics (Brodie et al. 2011), is gaining traction in the literature (Calder et al. 2009; Van Doorn et al. 2010); thus fitting within the broader theoretical perspectives of consumer culture theory (Arnould and Thompson 2005), the service-dominant logic (Vargo and Lusch 2004, 2008; Karpen et al. 2012), and relationship marketing (Vivek et al. 2012). Brodie et al. (2011) define 'customer engagement' as "a psychological state that occurs by virtue of interactive, co-creative customer experiences with a focal agent/object (e.g. a brand)." The rationale underlying this observed shift is a growing scholarly recognition of contemporary consumers' active, rather than passive, roles and behaviors in specific brand-based processes (Pagani, Hofacker and Goldsmith 2011; Singh and Sonnenburg 2012; Prahalad 2004; Hoffman and Novak 1996; Ramani and Kumar 2008). However, despite preliminary claims, insights into consumers' 'engagement'-related dynamics remain sparse and largely lacking measurement capability and empirical validation to date. 
Increasing levels of consumers' brand engagement (CBE) are expected to be conducive to the attainment of superior organizational performance outcomes, including sales growth, cost reductions, brand referrals, enhanced consumer contributions to collaborative product development processes, enhanced co-creative experiences, and superior profitability (Sawhney et al. 2005; Nambisan and Baron 2007; Prahalad 2004; Bijmolt et al. 2010). Consequently, CBE has been viewed to represent a key new metric for gauging brand performance (Kumar et al. 2010; Bowden 2009; MSI 2010).

Despite significant practitioner interest, the undertaking of scholarly, empirical CBE research has lagged behind, resulting in a limited understanding of the concept and its measurement to date (Bolton 2011; Verhoef et al. 2010). As such, this research responds directly to the Marketing Science Institute's (MSI 2010), Leeflang's (2011), and Brodie et al.'s (2011) calls for the undertaking of 'engagement' scale development research in marketing. A key exception is provided by Calder et al.'s (2009: p. 322) 'online engagement' (OE) scale designed to measure the secondorder construct of engagement manifested in "various types of first-order experiences." Despite important insights gleaned, the authors' perspective differs, conceptually, to ours in at least three ways.

First, in contrast to Calder et al. (2009), our proposed model explicitly reflects consumers' engagement with specific brands. Second, as outlined in the section titled 'CBE Conceptual Development, the notion of interactive consumer/brand relationships pervades each of our proposed CBE dimensions, rather than existing as an independent dimension; as in Calder et al.'s model. Third, we offer a more parsimonious 10-item measurement tool comprising three CBE dimensions, relative to Calder et al.'s proposed eight-dimensional view of OE comprising 37 items. 
Further, our model exhibits conceptual divergence from Sprott et al.'s (2009) 'brand engagement in self-concept' (BESC) scale designed to gauge 'an individual difference representing consumers' propensity to include important brands as part of how they view themselves” (p. 92). Specifically, following Brodie et al. (2011), we posit 'interactive experience' to represent a core hallmark typifying 'engagement.' However, the conceptual scope of BESC limits the emergence of the interactive nature of 'engagement' (Leeflang, 2011; Bezjian-Avery et al. 1998). Hence we adopt a more comprehensive approach focused on the interactively generated nature of CBE, as outlined in further depth in the Literature Review. Specifically, in four studies we conceptualize CBE, and develop and validate a CBE measurement scale.

The CBE scale developed in this paper is expected to generate the following contributions. First, we anticipate the future deployment of our scale to generate enhanced managerial knowledge regarding the attainment of enhanced organizational performance outcomes, including heightened consumer brand loyalty. Second, the proposed CBE conceptualization and scale contribute novel insights to the emerging 'engagement' literature in marketing. This paper's objectives include first, by developing a CBE conceptualization and an associated measurement instrument, which builds directly on previous research, this paper seeks to contribute further insights into the nature, dimensionality and measurement of 'engagement,' which are limited in the literature to date. Second, by exploring focal CBE conceptual relationships, we provide an enhanced understanding of the nature and directionality of these specific conceptual associations. Third, we show the CBE scale exhibits construct validity.

The paper is structured as follows. The next section provides a literature review, followed by an overview of the exploratory qualitative research undertaken for the definitional and conceptual development of CBE (study 1). Next, study 2 applies the proposed CBE conceptualization in a 
series of exploratory factor analyses to better understand the factorial structure, dimensionality and preliminary items reflecting CBE using a sample of 194 undergraduate students. Employing a new sample of 554 consumers, study 3 documents the undertaking of a series of confirmatory factor analyses serving to corroborate the three-factor, 10-item CBE scale. Next, we adopt an additional sample of 556 consumers in study 4 to explore CBE within a broader nomological net of conceptual relationships from which we draw a number of conclusions.

\section{Literature Review: 'Engagement'}

While 'engagement' has received considerable attention across a number of academic disciplines, including social psychology and organizational behavior, the concept has transpired in the marketing literature only relatively recently (Leeflang 2011; Brodie et al. 2011). In this emerging literature, 'engagement' has been viewed as a promising concept expected to provide enhanced predictive and explanatory power of focal consumer behavior outcomes, including brand loyalty (Pham and Avnet 2009; Avnet and Higgins 2006a/b; Schau et al. 2009).

\section{Table 1 about here}

We provide an overview of reviewed 'engagement' conceptualizations proposed in the marketing literature in Table 1, which reveals the following observations. First, we identify a number of 'engagement'-based concepts, including 'consumer-'and 'customer engagement' (Van Doorn et al. 2010; Brodie et al. 2013), 'community engagement' (Algesheimer et al. 2005), and so on. Specifically, the multiplicity of emerging 'engagement'-based concepts highlights the nascent developmental state of 'engagement' research in marketing to date. Following Brodie et al. (2013), the focus in the remainder of this paper is on consumers' engagement with particular brands. 
Second, 'engagement' reflects a motivational state (Van Doorn et al. 2010), which occurs by virtue of an individual's (i.e. the 'engagement subject') focal interactive experiences with a particular object or agent (i.e. the 'engagement object;' Hollebeek 2011a/b), which is key for many online offerings (Sawhney et al. 2005; Malthouse and Hofacker 2010; Shankar and Batra 2009). While key 'engagement subjects' cited in the literature include customers and consumers, specific ‘engagement objects' may include brands, offerings, organizations, and organizational activities occurring beyond purchase (Patterson et al. 2006; Van Doorn et al. 2010). Consequently, the concepts of 'customer engagement' and 'brand engagement' may reflect a highly similar conceptual scope, despite employing differing concept designations (i.e. names). While Van Doorn et al. (2010) offer highly valuable insights into the nature and dynamics characterizing 'customer engagement behaviors,' the authors adopt a more organization-centric, as opposed to consumercentric, lens as adopted in this paper.

Third, 'engagement' represents a multi-dimensional concept comprising relevant cognitive, emotional, and behavioral dimensions (Hollebeek 2011a/b; 2012), although the specific expression of focal 'engagement' dimensions may vary across contexts. To illustrate, while Calder et al. (2009) identify eight 'online engagement' (OE) dimensions (e.g. 'stimulation and inspiration'), Mollen and Wilson (2010) propose the three OE facets of active sustained processing, experiential value, and instrumental value. Fourth, 'engagement' plays a central role in a nomological net of focal conceptual relationships (Brodie et al. 2011), which is explored in further depth in the section titled 'CBE Conceptual Development.' Further, engagement exhibits conceptual distinctiveness from other, related concepts, including consumer 'involvement' (cf. study 4), and 'customer satisfaction.' To illustrate, 'customer satisfaction,' which is defined as “a customer's overall evaluation of the performance of an offering to-date" (Johnson and Fornell 1991; Gustaffson et al. 2005), has been viewed as an 'engagement' consequence with a potential positive relationship between these 
concepts (Brodie et al. 2011). Specifically, 'engagement,' in contrast to 'satisfaction,' is focused on consumers' cognitive, emotional and behavioral dynamics during specific brand interactions (whereas satisfaction may largely arise thereafter).

Fifth, as stated in the Introduction, we identified a limited number of 'engagement' scales in the marketing literature (e.g. Calder et al. 2009; Sprott et al. 2009); although these reflect distinct conceptual domains, relative to CBE. For example, in contrast to Calder et al. (2009: p. 322), we view 'experience' and 'engagement' to represent distinct theoretical entities (Lemke et al. 2011). In support of this point, Brakus et al. (2009) posit: "In contrast to brand 'involvement' [and thus, CBE] "brand experience does not presume a motivational state (p. 53);" and "brand experience [as opposed to CBE] is not an emotional relationship concept" (p. 54). Specifically, this research provides the first known empirical investigation of Brodie et al.'s (2011) and Hollebeek's (2011a/b) exploratory findings. As such, this research directly builds on, and extends, the work of these authors, adopting a positively valenced perspective on engagement.

\section{Study 1: Consumer Conceptions of 'Consumer Brand Engagement' (CBE)}

To further explore and define CBE, we conducted exploratory, qualitative research employing 10 consumer respondents whom we recruited through advertisements posted on community notice boards in a large Pacific Coast city. We instructed the participants to select a brand in any category that is 'highly engaging' to them, and to describe their 'engagement' with the brand to the researcher in the focus group and in-depth interviews conducted. In this study, we set out to explore the relevance and particular expressions of $\mathrm{CBE}$ across a range of contexts, from which we select a focal context of primary importance for the remaining studies reported in this paper. Further, the respondents were also asked to describe a brand, which they use or purchase, but which they do not 
feel they engage with at all (Brakus et al. 2009). Hence at this point we kept an open mind to the emergence of CBE with a range of brands, including specific social media.

While initially adopting an open-ended approach, we primed the respondents with terms related to the cognitive, emotional and behavioral facets of 'engagement' sourced from the literature review findings in the second part of the study; thus permitting a conservative assessment of whether consumers shared our conception of CBE and whether they perceived a difference between 'highly engaging' and 'non-engaging brands.' The third part of the study centered on exploring the nature of specific CBE conceptual relationships.

\section{Insert Table 2 about here}

An overview of the respondents' self-selected brands and key respondent quotes is provided in Table 2. As observed from Table 2, the audio recorded findings suggested that consumers predominantly equated their 'engagement' with their selected brands to specific brand interactions. Further, concurring with the findings reported in Table 1, the results indicated that for perceived 'highly engaging' brands consumers, typically, appeared willing to exert considerable cognitive, emotional and behavioral activity in their brand interactions; thus reflecting the core interactive nature underlying the 'engagement' concept (Leeflang 2011; Brodie et al. 2011).

Content analysis of the responses revealed the respondents reported their 'engagement' with their selected brand to occur predominantly during focal brand interactions. ${ }^{1}$ As Ben (54) illustrates, the respondents also perceived 'engagement' to be evoked by focal brand-related stimuli during brand interactions:

\footnotetext{
${ }^{1}$ One of the respondents did not provide a specific 'non-engaging' brand, but described a focal 'non-engaging' category generically (i.e. stationery). Although this respondent did not strictly follow the instructions, we included the individual's response to avoid biasing the results.
} 
"[When I am at Health \& Sports Gym] everything linked to the brand is tying in with [me] trying ... to stay fit and healthy; the brand is Health \& Sports. I'm constantly thinking about that. I'm focused on what the brand is about."

We present three descriptions illustrating each of the respondents' self-selected brands in Table

2, which reveals the participants' described the cognitive (e.g. "[iPod] can take up all my attention;" Jake, 20), emotional (e.g. “I love Merc[edes-Benz];” Eve, 65) and behavioral (e.g. "Sunday night 19:30 I'm there [for The Amazing Race];” Andrew, 39) facets of CBE.

We also analyzed the descriptions for the 'non-engaging' brands. For these brands, the respondents exhibited a substantially lower willingness to exert cognitive, emotional or behavioral activity in their brand interactions, as evident from the right-hand column of Table 2 . In contrast to the 'highly engaging' brands, participants described their selected 'non-engaging' brands primarily in terms of price-consciousness and functionality (i.e. brands perceived as necessities, or a predominant focus on utilitarian, as opposed to hedonic, brand characteristics). To illustrate,

"When I go into [The National Bank, i.e. non-engaging brand], when I'm engaging with the staff, it's more like just going through the motions, through the routine... I can't be bothered to answer all the questions they have for me. Whereas at [Health \& Sports Gym, i.e. highly engaging brand], I will genuinely be talking to the staff, genuinely interested in them, and what they are all about" (Ben, 54).

All descriptions of 'highly engaging' brands adopted a positive valence (Table 2), as reflected in the $\mathrm{CBE}$ conceptualization proposed in the next section. In summary, the qualitative study shows consumer conceptions of CBE are aligned with key findings addressing the 'engagement' concept in prior research (Brodie et al. 2011; Leeflang 2011). We introduce our proposed CBE conceptualization in the next section.

\section{CBE Conceptual Development}

Based on the literature review and the exploratory qualitative research findings, we develop a CBE conceptualization in this section. Specifically, CBE reflects the core theoretical notion of 
'interactive experience' underlying the 'engagement' concept (Brodie et al. 2011), as outlined in the Literature Review. In the conceptual designation of CBE, we address the consumer as the focal 'engagement subject' (e.g. applicable to specific social media settings, as opposed to paying customers); while the specific 'engagement object' (i.e. the brand) is made explicit in the concept name. Specifically, we conceptualize CBE as:

A consumer's positively valenced brand-related cognitive, emotional and behavioral activity during or related to focal consumer/brand interactions.

Further, analogous to the literature review- and qualitative research-informed findings, we propose three CBE dimensions, which correspond to the generic cognitive, emotional and behavioral nature of 'engagement.' First, 'cognitive processing' is defined as “a consumer's level of brand-related thought processing and elaboration in a particular consumer/brand interaction” (i.e. cognitive CBE dimension). Second, ‘affection' refers to “a consumer's degree of positive brandrelated affect in a particular consumer/brand interaction" (i.e. emotional CBE dimension). Based on the positively valenced nature underlying $\mathrm{CBE}$, we selected the term 'affection,' rather than the more neutrally valenced term 'affect.' Third, 'activation' is defined as 'a consumer's level of energy, effort and time spent on a brand in a particular consumer/brand interaction" (i.e. behavioral CBE dimension).

CBE represents a composite concept comprising the constituent concept of the 'brand.' In this research, we adopt a holistic perspective of the brand, which covers consumers' perceived utilitarian, as well as more hedonic, or symbolic aspects of brands. To illustrate, Brown et al. (2006) define a 'brand' as the "totality of all stakeholders' mental associations about the organization" and related objects (e.g. the website; Stern 2006). 
As outlined, CBE differs, conceptually, from other phenomenological concepts. Specifically, we hypothesize a particular nature of specific $\mathrm{CBE}$ conceptual relationships, which we proceed to empirically test in study 4 (For further detail regarding the nature of specific CBE conceptual relationships derived in study 1 , please refer the Appendix).

The remainder of this paper is structured as follows. We develop a CBE scale that captures the dimensions of CBE and the level of CBE evoked by focal brands on each dimension, which first requires a literature- and qualitative research-informed search for acceptable items. In study 1 , we select initial items along specific proposed CBE dimensions, and ask consumers, managers and experts to screen these items. In study 2, we ask 194 undergraduate students to rate the remaining items with reference to the Facebook.com brand, and conduct an exploratory factor analysis to determine the dimensionality of the scale. In study 3, applying the preliminary scale to a new sample of 554 consumers who use the Twitter.com brand, we adopt confirmatory factor analyses to further determine the scale's dimensionality. In study 4, we re-examine the scale's dimensionality by using a new sample of 556 consumers who use the LinkedIn.com brand, and model CBE within a broader nomological net. We also examine the scale's construct validity, and provide insights into the nature of specific theoretical associations between CBE and its focal antecedents and consequences.

\section{CBE Measurement Item Generation \& Selection}

The objective of the preliminary study reported in this section was to generate specific items for the proposed dimensions of $\mathrm{CBE}$ and to select the items that have face validity. To generate the items, we consulted the literature review and study 1 (Calder et al. 2009; Sprott et al. 2009). From these analyses, we developed 69 items to reflect $\mathrm{CBE}$, including 23 items representing 'cognitive processing,' 30 items reflecting 'affection,' and 16 items for 'activation.' The selected items were 
worded so as to create linguistic style consistency for the scale so that a reference to a focal brand appeared in each item and referred to a consumer's CBE with the focal brand. We performed an initial face validity check, which indicated the potential suitability of the 69 items to measure CBE.

Following Brakus et al. (2009), we screened the items by using a CBE stakeholder panel comprising 6 consumers ( 3 male), 2 managers ( 1 male) and 4 academic experts ( 3 male). The respondents were known to the researcher; and as such, convenience sampling was used in this phase of the research. We asked the respondents to self-select a brand with which they felt to be 'highly engaged,' which generated brands including Facebook.com and LinkedIn.com.

Employing an in-depth interviewing format, we explained the CBE concept to the screening participants, and asked the respondents to evaluate the extent to which the 69 items described their 'engagement' with their self-selected brands. All items were positively worded. We used the panelists' recommendations to further assess the preliminary CBE item pool, guide specific item additions/deletions, and to improve the item wording, as required (Churchill 1979); thus contributing to the establishment of content validity for the preliminary CBE scale.

\section{Results}

The item screening generated a reduced pool of $39 \mathrm{CBE}$ items. The specific 30 item deletions were based on: (i) Duplication in item scope or content; and (ii) Sub-optimal capturing of the conceptual domain of CBE. To illustrate, the preliminary item "To me, using [brand] is challenging" was found to have limited applicability in reflecting the respondents' CBE, and was thus omitted from further analyses.

While several of the initial items had relevance for consumers' CBE across contexts, others were found to exhibit a lack of cross-context transferability, and were therefore removed from further analyses. To illustrate, the items "Using [brand] is a treat for me," and "Using [brand] is fun" were 
found to have lesser applicability for perceived utilitarian brands and necessities, which the consumer may use out of perceived need (Voss et al. 2003), rather than resultant from feeling 'highly engaged' with the brand per se. Further, the item '[Brand] often gives me something to talk about" may be less relevant for privately, as opposed to conspicuously, consumed brands. Hence as a result of the item screening procedures, we retained 12 items for the 'cognitive processing,' 15 items for the 'affection,' and 12 items for the 'activation' dimensions of CBE for further analysis.

\section{Study 2: CBE Measurement Assessment \& Scale Dimensionality}

Following Churchill (1979), we designed study 2 to further reduce the 39-item pool reflecting $\mathrm{CBE}$, and to examine the following: (i) How many CBE dimensions exist?; and (ii) Which particular types of consumers' CBE expressions are captured by these dimensions?

To achieve these objectives, we selected the brand Facebook.com for investigation, which represents a social media brand allowing individuals to personalize their social network and applications, in addition to facilitating text, pictorial, video, gaming and other forms of communication. We selected a social media setting in studies 1-3 based on the considerable relevance of, and scholarly and managerial interest in, the 'engagement' concept in interactive Web 2.0, including social media, settings (Hoffman and Novak 2012; Briggs 2010; Byrne 2008; HennigThurau et al. 2010).

Kaplan and Haenlein (2010: p. 61) define 'social media' as "a group of Internet-based applications that build on the ideological and technological foundations of Web 2.0, and which allow the creation/exchange of user-generated content," including Facebook.com and Twitter.com (Boyd and Ellison 2008). Specifically, the interactive capabilities of social media provide a conceptual parallel to the interactively generated nature underlying the 'engagement' concept. To illustrate, by providing access to online content and facilitating communication, social media may 
connect consumers and organizations, thus fostering consumer 'engagement' (De Valck et al. 2009; Van Laer et al. 2013).

We administered a questionnaire comprising the remaining $39 \mathrm{CBE}$ items applied to the Facebook.com brand to a sample of 194 undergraduate Business students from a large university in a metropolitan area in October 2011 (90.7\% under the age of 25; 53.1\% male; $44.3 \%$ of European descent). Each of the participants reported using the Facebook.com brand, and took approximately ten minutes to complete the questionnaire.

To reduce the occurrence of primacy and recency effects, we developed three different questionnaire versions employing a distinct, randomly assigned sequence of the remaining $\mathrm{CBE}$ items, which were rated on seven-point Likert scales anchored in 'strongly disagree' (1) through to 'strongly agree' (7). We incentivized the students to participate in the study by means of a voluntary prize draw, which provided the opportunity to win one of two iTunes vouchers. With a total of 254 distributed surveys, 196 questionnaires were returned to the researcher; thus generating a response rate of $77.2 \%$. Of these, two unusable (incomplete) responses were removed from further analyses; thus resulting in a total of 194 useable responses. To analyze the data, we employed exploratory factor-analytic (EFA) procedures using principal axis factoring with oblique rotation, to extract the CBE factors (Conway and Huffcut 2003; Byrne 2010).

\section{Results}

As anticipated, the respondents showed a substantial spread of their reported CBE levels with the Facebook.com brand, which represents an important criterion in scale development research. We report a KMO statistic of .921 ; thus suggesting a factor structure is likely to underlie the data. Bartlett's test of spherity for the correlation matrix: $\chi^{2}(741)=4913.922(p=0.000)$; indicating the existence of large correlations amongst the variables. Based on Cattell (1966), we observed the 
scree in the scree plot at three factors; thus corresponding to our hypothesized three-factor model of CBE.

In the pattern matrix, for $n=200$, Hair et al. (2010: p. 117) recommend a critical factor loading of .40 to achieve significance $(p<.05)$. Based on this analysis we consecutively removed several items resulting in a three-factor, 10-item CBE scale for further analysis. Each of the 10 items loaded onto its intended factor: (i) The three proposed 'cognitive processing' items loaded onto factor 3; (ii) The four 'affection' items loaded onto factor 1 (iii) The three 'activation' items loaded onto factor 2. Reliability (internal consistency) analyses using Cronbach's alpha indicated the scale had good reliability: (i) Cognitive processing: .753; (ii) Affection: .839; (iii) Activation: .776; and (iv) Overall 10-item CBE scale: .823. In an additional EFA including only the 10 retained CBE items, the scree plot and the eigen values exceeding 1.0 concurred in suggesting the suitability of a threefactor solution for CBE, which explained $69.63 \%$ of the total variance.

The analyses reported in this section also provided evidence for the convergent validity of the preliminary three-factor, 10-item CBE scale. Further, we conducted Fornell-Larcker tests for discriminant validity for each of the three possible CBE dimension pairs (i.e. COG. PROCAFFEC.; COG. PROC.-ACTIV.; and AFFEC.-ACTIV.), which indicated the three CBE dimensions exhibited discriminant validity (Fornell and Larcker 1981a/b); that is, the Average Variance Extracted exceeded the squared correlation for the specific paired constructs. Hence we adopted the three-factor, 10-item CBE scale for validation in study 3.

\section{Study 3: CBE Scale Refinement \& Confirmation}

The objective of study 3 was to refine (if required) and confirm the preliminary, 10-item CBE scale. To test the stability of the scale, as well as the external validity, we employed a new sample of respondents and a different brand, which enabled us to examine whether the responses to the 
scale were truly respondent- and brand independent within the social media context. The sample comprised 554 consumers from an independent marketing fieldwork organization, and reflected the following demographic profile: $16 \%$ aged $30-34 ; 13 \%$ aged $50+; 38 \%$ male; $74 \%$ of European descent.

Employing the reduced, 10-item scale and our new sample of 554 consumers, we conducted confirmatory factor analyses to confirm the CBE scale's dimensionality, and arrive at the final CBE scale. To achieve this objective, we selected the social media brand Twitter.com for investigation (Russell 2011). We selected Twitter.com based on the brand's significant and growing popularity, and the expected substantial spread of consumer CBE levels with this brand.

The questionnaire, which took approximately five minutes to complete, included a screening question verifying the respondents used the Twitter.com brand. Targeting 5994 prospective respondents, we attained 554 responses; thus generating a response rate of $9.2 \%$. To analyze the data, we employed confirmatory factor analysis (CFA) in order to fit the model to the data using maximum likelihood estimation (Byrne 2010; Bollen 1989).

\section{Results}

\section{Insert Figure 1 about here}

The results in Figure 1 suggested excellent model fit (Iacobucci 2010: p. 91): $\chi^{2}(32)=97.994$ $(p=0.000) ;$ and $\chi^{2} / d f=3.06$. Further, GFI $=.968 ; \mathrm{CFI}=.984 ; \mathrm{RMSEA}=.061 ;$ and $\mathrm{SRMR}=.0278 ;$ thus corroborating the excellent model fit to the data (Bagozzi and Yi 2012, 1998; Bentler 1990; Steiger 1990). The regression weights $(\beta s)$ for each of the items onto their intended factor were significant (e.g. AFFECTION $\rightarrow$ AFFEC. 1: .895); and all standardized coefficients $>.50$; 
suggesting that each of the items should remain in the model (Hildebrandt 1987; Steenkamp and Van Trijp 1991: p. 289).

The attained Cronbach alphas for the scale were: (i) Cognitive processing: .825; (ii) Affection: .907; (iii) Activation: .894; and (iv) Overall CBE scale: .933. These findings also suggest the scale has convergent validity. Further, following examination of the Average Variance Extracted statistics, the Fornell-Larcker test results (Table 3) suggested that two of the three CBE dimensions had discriminant validity. The CBE scale was re-estimated using a two-factor model based on Bagozzi and Phillips' (1982) recommendations, and an alternate two-factor model (Factor 1: COG. PROC. combined with AFFEC.; and Factor 2 with ACTIV.) was estimated. The fit statistics for the re-estimated model were as follows: $\chi^{2}(53)=464.9(p=0.000)$; and $\chi^{2} / d f=8.72$, GFI $=.865$; CFI $=.922 ; \mathrm{RMSEA}=.118 ;$ and SRMR $=.048 ;$ thus indicating a worse fit, relative to the three-factor model. As such, study 3 confirmed the CBE scale representing a valid, reliable and stable measurement instrument.

\section{Insert Table 3 here}

\section{Study 4: CBE Scale Validation \& Exploring CBE Conceptual Relationships}

In study 4, we examined the CBE scale within a nomological net of focal CBE conceptual consumer/brand-based relationships (Figure 2), tested the research hypotheses developed in the section titled 'CBE Conceptual Development,' and further validated the scale. We proceed by providing an overview of the brand selection, data source and sample, and results.

This sub-section outlines the hypothesis testing undertaken for the CBE nomological net shown in Figure 2, which is based on the research hypotheses developed earlier. Specifically, based on the literature review and qualitative research-informed findings, we selected consumer brand 
'involvement' (INV) as a key CBE antecedent. Further, we adopted consumer 'self-brand connection' (SBC) and 'brand usage intent' (BUI; Mittal et al., 1999) as CBE consequences, as shown in Figure 2.

\section{Insert Figure 2 about here}

Employing the 10-item CBE scale and a new sample of 556 consumers who reported using the LinkedIn.com brand, we undertook a series of empirical tests of the research hypotheses. The sample demographics were as follows: $15 \%$ aged $30-34 ; 17 \%$ 45-49; $22 \%$ aged $50+; 45 \%$ male; and $74 \%$ of European descent.

We used maximum likelihood estimation to undertake the analyses (Bollen 1989: p. 107). To generate an optimally representative sample of the national online population, we imposed quotas for specific demographic categories, similar to study 3 . We then adopted convenience sampling to select individuals from each sub-set. Targeting 5327 prospective respondents, we attained 556 responses; thus generating a response rate of $10.4 \%$. We again administered the items in a random, computer generated order, and offered e-rewards to incentivize the participants. In Table 4, we provide an overview of the measures employed for the model constructs adopted and selected descriptive and reliability statistics.

\section{Insert Table 4 about here}

\section{Results}

\section{Model Results}

Before proceeding to the structural equation modeling assessments, we conducted confirmatory factor analyses (CFAs) to ensure adequate fit to the data for the individual model constructs (Iacobucci 2010; Steenkamp and Van Trijp 1991). The results for the 10-item consumer brand

'involvement' scale suggested inadequate model fit, for example: $\chi^{2}(35)=299.145 ; \chi^{2} / d f=8.547$; 
RMSEA $=.117$. Therefore based on the, items INV1, 3-4 and 7 (Table 4) were purified whilst aiming to retain the construct's theoretical integrity. The results for the reduced 6-item scale suggested good model fit: $\chi^{2}(9)=23.952 ; \chi^{2} / d f=2.661 ; \mathrm{GFI}=.986 ; \mathrm{CFI}=.994 ;$ RMSEA $=.055$; and SRMR $=.0126$.

The CFA results for the three-factor, 10-item CBE scale indicated the model provided excellent fit to the data: $\chi^{2}(32)=116.699 ; \chi^{2} / d f=3.647 ; \mathrm{GFI}=.956 ; \mathrm{CFI}=.981 ; \mathrm{RMSEA}=.069$; and SRMR $=.0336$, thus providing support for the results of studies 1 and 2 . Similarly, the results for the fouritem 'brand usage intent' scale suggested good model fit to the data: $\chi^{2}(2)=5.651 ; \chi^{2} / d f=2.826$; $\mathrm{GFI}=.995 ; \mathrm{CFI}=.998 ; \mathrm{RMSEA}=.057 ;$ and SRMR $=.0079$. Therefore we adopted the full, fouritem 'brand usage intent' scale in further analyses.

The CFA results for the consumer 'self-brand connection' scale, initially, provided inadequate model fit: $\chi^{2}(14)=156.304 ; \chi^{2} / d f=11.165 ;$ RMSEA $=.135$. Based on the modification indices, the consecutive removal of items SBC4-6 generated enhanced model fit: $\chi^{2}(2)=2.423 ; \chi^{2} / d f=1.212$; $\mathrm{CFI}=1.00 ;$ and SRMR $=.0051$. We hence employed the reduced, four-item self-brand connection scale in further analyses.

We also undertook a CFA measurement model comprising all model constructs, which we tested for discriminant validity using the Fornell-Larcker test procedure (Fornell and Larcker 1981a/b), which indicated that discriminant validity was attained for 14 of the 15 possible construct pairs; that is, with the exception of COG. PROC.-AFFEC. (Table 5). As discriminant validity was not shown for this construct pair, further testing was undertaken based on Bagozzi and Phillips' (1982: p. 476) procedure. This method involved the undertaking of base (unconstrained) model comparisons to similar models in which the relevant correlations (covariances; $\beta \mathrm{s}$ ) were constrained equal to 1.0 ; a 
$\chi^{2}$ difference value with an associated $p$-value of less than .05 supports the discriminant validity hypothesis.

We tested the COG. PROC.-AFFEC. construct pair as one factor in the model, which included an assessment of the $\Delta \chi 2(\Delta d f)$, relative to the tabled critical $\chi 2$ value (i.e., $3.84 ; p<.05$; Aaker et al. 2004). Specifically, $\Delta \chi 2$ (1) was 4.728 for the one factor construct pair, which exceeded the 3.84 threshold. Hence the Bagozzi-Phillips test result corroborated the existence of discriminant validity between the CBE 'cognitive processing' and 'affection' factors. Finally, Table 4 shows excellent Cronbach's alphas were attained for all measures employed in the model. Moreover, the correlation matrix provided evidence of the model's nomological validity. To illustrate, the highest correlations were observed between the items comprising focal constructs (e.g. AFFEC. 1 - AFFEC. 3: .788).

The findings indicated the model (Figure 2) provided good fit to the data (Marsh, Hau and Wen 2004): $\chi^{2}(243)=1019.548 ; \chi^{2} / d f=4.196 ; \mathrm{CFI}=.940 ; \mathrm{RMSEA}=.076 ;$ and SRMR $=.0525$. The regression coefficients indicated that each of the items made a significant contribution to the measurement of its intended construct, thus contributing to the model's convergent validity.

A stronger condition for convergent validity is that the correlation between a focal item and its latent construct should be greater than .50 (Hildebrandt 1987), which was also met for each of the relevant coefficients (e.g. for consumer brand involvement: INV $\rightarrow$ INV 9: .974). Each of the squared multiple correlations exceeded .50; also indicating good item reliability. Further, the standardized regression weights for all items onto their intended factor were greater than .70 in magnitude. However, we found the structural pathway from COG. PROC. $\rightarrow$ BUI to be nonsignificant $(t=.844 ; p=.399)$. With all reported $C R$ values $>.70$, the results in Table 4 indicate the model exhibits construct reliability. Overall, the above analyses suggested the proposed model has construct validity. 


\section{Insert Table 5 about here}

Further, to evaluate model stability, the sample was randomly split into calibration and validation sub-samples of 278 respondents each (Cohen 1988). Highly similar results were attained across both sub-samples (Table 6), which also exhibited significant resemblance to the results for the full sample (Alwin and Jackson 1981). The fit statistics for the calibration sample are: $\chi^{2}(243)=$ $653.561(p=0.000) ;$ and $\chi^{2} / d f=2.69, \mathrm{GFI}=.824 ; \mathrm{CFI}=.932 ; \mathrm{RMSEA}=.078 ;$ and $\mathrm{SRMR}=.0616$; the validation sample: $\chi^{2}(243)=666.7(p=0.000) ; \chi^{2} / d f=2.77, \mathrm{GFI}=.817 ; \mathrm{CFI}=.938 ; \mathrm{RMSEA}=$ .079 ; and SRMR $=.0516$. Therefore, the split-sample results provided support for the stability of the model, thus contributing to its validity.

To further validate the model, we tested for mediation effects by applying Zhao, Lynch and Chen's (2010) recommendations, which posit the key condition in showing mediation is "that the indirect effect is significant" (p. 204). We employed bootstrapping procedures, which facilitated the exploration of the multiple CBE mediators simultaneously in the association between focal independent (i.e. consumer brand 'involvement') and dependent variables (e.g. 'self-brand connection;' Preacher and Hayes 2008). Based on Zhao et al. (2010), we applied the recommended 5000 bootstrap samples at the $95 \%$ confidence level.

We first examined the indirect effects of consumer brand 'involvement' on consumer 'self-brand connection' with the CBE mediators of cognitive processing, affection and activation. The results showed the existence of a significant indirect effect of consumer brand involvement on self-brand connection with the three CBE mediators: $\beta=0.776$; standard error $(\mathrm{SE})=0.10 ; 95 \%$ confidence interval $(\mathrm{CI})=.600$ to $.984(p=0.00)$; thus suggesting that $\mathrm{CBE}$ mediates the association between consumer brand 'involvement' and consumer 'self-brand connection.' However, the direct effect of 
consumer brand 'involvement' on consumer 'self-brand connection' showed partial mediation $(\beta=$ 0.638; $p=0.000$ ); thus corresponding to Zhao et al.'s (2010) 'complementary' mediation.

Second, we examined the indirect effects of consumer brand 'involvement' on 'brand usage intent' with the CBE mediators of cognitive processing, affection and activation. The results showed a significant indirect effect of consumer brand 'involvement' on 'brand usage intent' with the three CBE mediators: $\beta=0.357$; $\mathrm{SE}=0.08 ; 95 \% \mathrm{CI}=.196$ to $.510(p=0.00)$. Because the confidence interval did not include the value of 0.0 , we identified a mediating effect of $\mathrm{CBE}$ in the association between consumer brand 'involvement' and 'brand usage intent.'

We also identified the following, non-significant direct effect of consumer 'involvement' on 'brand usage intent:' $\beta=-0.057(p=0.557)$; thus suggesting the existence of complete mediation. This result corresponds to Zhao et al.'s (2010) 'indirect-only' mediation, which implies there are no omitted mediating variables, and the mediating hypotheses are supported. Further, the meditation testing we undertook using Baron and Kenny's (1986) procedure produced highly similar results to those attained using Zhao et al.'s (2010) method; thus suggesting CBE mediates the association between consumer 'involvement' and consumer 'self-brand connection,' and 'brand usage intent,' respectively.

\section{Insert Table 6 about here}

\section{Alternative Model}

Next, we examine a competing nomological net where the more attitudinal CBE factors (i.e. COG. PROC. and AFFEC.) drive the behavioral CBE factor (i.e. ACTIV.; Fishbein and Ajzen

$1975)$, as shown in Figure 3. The following fit statistics were obtained: $\chi^{2}(246)=1231.664 ; \chi^{2} / d f=$ $5.007 ; \mathrm{CFI}=.924 ; \mathrm{RMSEA}=.085 ;$ and $\mathrm{SRMR}=.0534$. While each of the pathways for this model was statistically significant $(p<.05)$, the model provided a worse fit to the data, relative to the 
original model. Standardized regression weights for the model pathways were as follows ( $t$ values): INV. to COG. PROC. $=.817(18.8)$, INV to AFFEC. $=.910(22.9)$, COG. PROC. to ACTIV. $=$ .254 (6.38), AFFEC. to ACTIV. $=.751(15.6), \mathrm{ACTIV}$. to $\mathrm{SBC}=.910(19.8)$, and ACTIV. to BUI = .811 (17.1). Squared multiple correlations were $\mathrm{SBC}=.831$ and $\mathrm{BUI}=.657$. Hence on balance, we consider the original model a superior fit to the data, relative to the rival model.

\section{Insert Figure 3 about here}

\section{Hypothesis Testing Results}

Table 6 provides an overview of the hypothesis testing results. First, we found consumer brand 'involvement' to exhibit a significant relationship with each of the three CBE factors of cognitive processing, affection and activation, as expected $\left(\mathrm{H}_{1 \mathrm{a}^{-} \mathrm{c}}\right)$. Specifically, consumer brand 'involvement' has the greatest impact on the CBE 'affection' construct. Overall, we conclude consumer brand 'involvement' exerts a positive effect on CBE. Further, we attained evidence supporting the existence of a positive association between 'cognitive processing,' 'affection' and 'activation' on the one hand, and consumer 'self-brand connection' on the other. Furthermore, of the CBE dimensions, we found 'affection' to have the greatest effect on 'self-brand connection.' Moreover, we attained $\mathrm{R}^{2}=84 \%$ for 'self-brand connection;' thus indicating that not only does CBE have a positive effect on consumer 'self-brand connection,' but CBE explains most of the variance observed for this construct.

Similarly, while we found consumers' brand-related 'affection' (.426) and 'activation' (.402) in specific consumer/brand interactions to exert a similar significant effect on individuals' ensuing 'brand usage intent,' consumers' level of 'cognitive processing' (.045) failed to produce a significant effect. Relative to 'self-brand connection,' the effects of CBE on 'brand usage intent' were smaller, as indicated by the $\mathrm{R}^{2}=.651$. Based on this finding, managers aiming to develop 
consumers' 'brand usage intent,' which comprises a loyalty component, may wish to focus on activities and tactics fostering consumer 'affection' and 'activation,' as opposed to 'cognitive processing,' to achieve their strategic social media objectives. Of the three CBE constructs, it is 'affection' that most prominently influences 'brand usage intent' and 'self-brand connection.' Correspondingly, Sprott et al. (2009) identify positive effects of 'brand engagement in self-concept' on consumers' brand identification; although the authors' proposed instrument adopts a lesser focus on consumers' focal behavioral 'engagement' expressions. However, further research is needed to validate these exploratory findings, and gain additional insights into this emerging area, as addressed in the next section.

\section{Contributions, Limitations \& Implications}

\section{Academic Implications}

This paper has addressed the following objectives. First, we develop a CBE conceptualization and an associated CBE measurement scale, which contributes further insights into the nature and dimensionality of the 'engagement' concept within the broader theoretical area of interactive consumer/brand relationships. Overall, the research reported in this paper provides the first known empirical investigation of Brodie et al.’s (2011) and Hollebeek's (2011a/b) predominantly conceptual/exploratory findings. The CBE scale developed in studies 1-2, was validated in study 3 and its predictive validity confirmed in study 4 . In each of these studies the CBE scale exhibited good model fit. Second, we explored specific CBE theoretical relationships, including with consumer brand 'involvement,' 'self-brand connection' and 'brand usage intent,' which served to develop scholarly understanding regarding the nature and directionality of these specific conceptual associations. Third, based on the deployment of different brands (i.e. Facebook, Twitter, or LinkedIn) and samples across our three empirical studies, our analyses suggest the CBE scale has construct validity. 
In summary, studies 1-4 indicated that CBE: (a) Represents a promising, under-explored concept to date; (b) Has relevance in focal broader theoretical perspectives focused on specific interactive consumer/brand relationships, including consumer culture theory, S-D logic and relationship marketing (Brodie et al. 2011); (c) Exhibits significant associations with other marketing constructs (e.g. consumer brand 'involvement'); and as such, may be useful for scholars and managers seeking to predict specific consumer behavior outcomes; and (d) Warrants further investigation, as addressed in further depth in this section.

By proposing a CBE conceptualization and an associated diagnostic tool, this research provides a number of exploratory insights into the nature and dimensionality of this emerging concept. As such, this research responds directly to the Marketing Science Institute's (MSI 2010), Leeflang's (2011), and Brodie et al.'s (2011) call for the undertaking of 'engagement'-based scale development research. Further, this research has provided initial insights into the role of CBE within a net of focal nomological online relationships, including with consumer brand 'involvement,' 'self-brand connection,' and consumer-perceived 'brand usage intent.'

Additionally, this paper contributes insights regarding the potential role of $\mathrm{CBE}$ in the advancement of the broader theoretical perspectives of relationship marketing, S-D logic and consumer culture theory, which are centered upon the importance of establishing and maintaining value-laden, interactive and co-creative consumer/brand interactions and relationships. Moreover, this research provides a catalyst for future inquiry, which is required to validate the proposed CBE conceptualization and measurement instrument.

Despite these contributions, this research is also subject to several limitations. First, future scale validation and application across different types of online settings and different brands is required. While the authors designed the CBE scale with a view to having applicability across a range of 
settings and brands, including offline contexts, the empirical research in studies 2-4 has been limited to the investigation of particular social media settings. Therefore, future research validating the CBE scale across a range of other online contexts and brands is required. Further, while we undertook an initial validation study of the CBE scale, further study is required to fully validate the scale. Specifically, we reported the CBE scale to be subject to specific statistical limitations, including moderate levels of convergent and discriminant validity. Future researchers, therefore, may wish to deploy the scale in alternate nomological networks incorporating constructs such as 'brand love' and 'brand experience' to further validate the CBE scale.

Second, the cross-sectional nature of this research, and the majority of 'engagement'-based marketing research to date, is limited to a snapshot of consumers' CBE at a specific point in time. Therefore research adopting longitudinal (e.g. panel) designs would serve to contribute insights into specific CBE phases or cycles by describing focal patterns of change (Menard 2002), which may be investigated by using time series or latent growth curve analysis (Leeflang et al. 2009; Bijleveld et al. 1998).

To illustrate, longitudinal models may facilitate the investigation of focal CBE dynamics, which may differ across long-term or repeat, versus more recent or intermittent brand users. Future research may also wish to address the nature and dynamics pertaining to specific $\mathrm{CBE}$ triggers and inhibiting factors, which may be used to inform managerial decision-making.

Additionally, future investigations may wish to examine the potential contributions of $\mathrm{CBE}$ to the development of distinct (e.g. consumer-, or firm-perceived) forms of online 'brand usage intent' for focal organizations and brands (Keller 1993). Moreover, when examining CBE in longitudinal research designs, the nature of specific constructs acting as CBE antecedents or consequences may 
also be debated. To illustrate, while 'self-brand connection' and 'brand usage intent' were included as $\mathrm{CBE}$ consequences in the nomological network (study 4), longitudinal investigation of CBE over multiple consumer/brand interactions (e.g. a consumer's repeat brand usage) may render relevance of these constructs as $\mathrm{CBE}$ antecedents; that is, consumer dynamics based on previous brand experience, which occur prior to the undertaking of a focal brand interaction. Hence future research may wish to investigate the nature of specific constructs in relation to $\mathrm{CBE}$ across multiple brand interactions, and/or over time. Specifically, investigations in this area may uncover novel insights into the nature of particular, relatively ephemeral engagement states (Brodie et al. 2011), which we expect to exhibit a degree of continuity for specific individuals and brands. As such, to what extent may focal aggregated consumer engagement states exhibit conceptual similarity to particular, more enduring consumer traits?

Third, whilst consumer culture theory, S-D logic and relationship marketing provide ostensibly suitable conceptual foundations for $\mathrm{CBE}$, the nascent developmental state of $\mathrm{CBE}$ research merits further scrutiny of alternate, or supplementary, theoretical lenses through which to view the concept and its associated dynamics (Brodie et al. 2011). An example of such alternate or complementary perspectives include the Nordic School's service logic (Grönroos 2006); which despite a degree of conceptual similarity, exhibits focal differences, relative to S-D logic. Further, Bolton (2011) advocates the adoption of a 'co-creation perspective' of customer engagement (Grönroos and Voima 2012).

Research questions include: How may CBE be used to predict specific S-D logic, as opposed to service logic, outcomes? Is CBE always positive for organizations (Libai 2011); or do, for instance, optimal CBE levels exist, up to which heightened CBE levels engender increasingly favorable outcomes (e.g. enhanced consumer loyalty); yet beyond which sub-optimal results occur, which are 
detrimental to focal CBE stakeholders? What effect may specific negatively (as opposed to positively) valenced expressions of consumers' engagement with particular brands have on organizational performance outcomes? How can organizations manage this process? Further, we posit the 'brand interaction' concept to entail an unspecified temporal duration. As a result, consumers' CBE levels with a focal brand may fluctuate: (i) During (i.e. within) a particular brand interaction; and (ii) Across brand interactions over time. Therefore, future research may wish to examine the development of consumers' CBE levels within and across focal brand interactions. Finally, how may the nature of particular (e.g. perceived utilitarian, versus hedonic) brands serve to affect consumers' ensuing CBE levels, online and offline (Scarpi 2012)?

\section{Managerial Implications}

In addition to scholarly contributions, this research also generates a number of managerial implications. First, by providing a CBE conceptualization, this work provides managers with an enhanced understanding of the emerging 'engagement' concept (Fournier and Avery 2011), which may be adopted in the design of specific CBE- or broader relationship marketing (e.g. loyalty)focused strategies and tactics. This research suggests a potential contributing role of $\mathrm{CBE}$ to specific consumer 'self-brand connection,' and 'brand usage intent' outcomes, which may represent useful information for managers.

Further managerial benefits may accrue from the adoption of the proposed CBE scale in specific organizational or brand-related settings. To illustrate, this research indicated that CBE may contribute to the development of consumer-perceived 'brand usage intent,' which is based, conceptually, on brand equity. Specifically, in today's highly competitive environment managers are challenged regarding how to best retain their profitable customers, who may exhibit specific switching behaviors. Hence practitioners' capability to measure and quantify consumer CBE levels, and assess these relative to specific key performance indicators, is expected to generate enhanced 
understanding of CBE and its outcomes, including consumer-perceived 'brand usage intent' and 'loyalty.'

Overall, we expect managerial cultivation of CBE to generate enhanced consumer brand retention and loyalty outcomes. Further, assessments of CBE may generate insights into the specific CBE dimensions on which particular consumers (or consumer segments) generate high (versus lower) scores for particular brands; thus facilitating the development of managerial insights into focal strong, versus weak, aspects of their brands; and permitting the emergence of insights into brand health and performance-related dynamics. To illustrate, based on the identified contribution of CBE to consumers' purchase intent of particular brands, managers may adopt the CBE scale not only to measure individuals' CBE levels (e.g. by undertaking consumer surveys), but also to facilitate the undertaking of enhanced predictability of consumers' future purchase intent for specific brands within their brand portfolios. Moreover, managerial adoption of the proposed scale is expected to contribute to the development of enhanced insight into consumers' specific cognitions, emotions and behaviors during particular brand interactions, which may be used for rethinking or redesigning the nature of specific consumer/brand interfaces for enhanced effectiveness. 


\section{Acknowledgment}

The authors would like to thank Professor Harald van Heerde from Massey University and Professor Mary Frances Luce from Duke University for their valuable feedback in the development of this paper. Further, the authors would like to thank the University of Auckland (Department of Marketing), for funding the data collection for studies 3 and 4. 


\section{References}

Aaker, David A., V. Kumar and George S. Day (2004), Marketing Research, New York: Chichester: Wiley.

Aaker, Jennifer, Susan Fournier and A.S. Brasel (2004), "When Good Brands Do Bad," Journal of Consumer Research, 31, June, 1-16.

Abdul-Ghani, Eathar, Ken Hyde and Roger Marshall (2010), "Emic and Etic Interpretations of Engagement with a Consumer-to-Consumer Online Auction Site," Journal of Business Research, 64, 10, 1060-1066.

Algesheimer, René, Utpal M. Dholakia and Andreas Hermann (2005), "The Social Influence of Brand Community: Evidence from European Car Clubs," Journal of Marketing, 69, July, 19-34.

Alwin, D.F. and David J. Jackson (1981), “Applications of Simultaneous Factor Analysis to Issues of Factorial Invariance," In: Jackson, D.F. and Borgatta, E.F. (Eds.), Factor Analysis and Measurement in Sociological Research: A Multi-Dimensional Perspective, Beverly Hills, CA: Sage, 249-279.

Arnould, Eric and Craig J. Thompson (2005), "Consumer Culture Theory: Twenty Years of Research, Journal of Consumer Research, 31, 4, 868-882.

Avnet, Tamar and E. Tory Higgins (2006a), "How Regulatory Fit Affects Value in Consumer Choices and Opinions," Journal of Marketing Research, 43, February, 1-10.

Avnet, Tamar and E. Tory Higgins (2006b), "Response to Comments on 'How Regulatory Fit Affects Value in Consumer Choices and Opinions," Journal of Marketing Research, 43, February, 24-27.

Bagozzi, Richard P. and Lynn W. Phillips (1982), "Representing and Testing Organizational Theories: A Holistic Construal," Administrative Science Quarterly, 27, 3, 459-489.

Bagozzi, Richard P. and Youjae Yi (1988), "On the Evaluation of Structural Equation Models,” Journal of the Academy of Marketing Science, 16, 1, 74-94.

Bagozzi, Richard P. and Youjae Yi (2012), "Specification, Evaluation, and Interpretation of Structural Equation Models," Journal of the Academy of Marketing Science, 40, 1, 8-34.

Baron, Reuben M. and David A. Kenny (1986), "The Moderator-Mediator Variable Distinction in Social Psychological Research: Conceptual, Strategic, and Statistical Considerations," Journal of Personality and Social Psychology, 51, 6, 1173-1182.

Bentler, Peter M. (1990), "Fit Indexes, Lagrange Multipliers, Constraint Changes and Incomplete Data in Structural Models," Multivariate Behavioral Research, 25, 2, 163-172.

Bezjian-Avery, A., Bobby Calder and Dawn Iacobucci (1998), "New Media Interactive Advertising vs. Traditional Advertising," Journal of Advertising Research, 38, 4, 23-32.

Bijleveld, Catrien J.H., Leo J. Th. Van Der Kamp, Ab Mooijaart, Willem A. Van Der Kloot, Rien Van Der Leenden and Eeke Van Der Brug (1998), “Longitudinal Data Analysis: Designs, Models, and Methods, London: Sage.

Bijmolt, Tammo H.A., Peter S.H. Leeflang, Frank Block, Maik Eisenbeiss, Bruce G.S. Hardie, Aurélie Lemmens and Peter Saffert (2010), "Analytics for Customer Engagement," Journal of Service Research, 13, 3, 341-356.

Bollen, Kenneth A. (1989), "Structural Equations with Latent Variables," New York: John Wiley.

Bolton, Ruth N. (2011), "Customer Engagement: Opportunities and Challenges for Organizations," Journal of Service Research, 14, 3, 272-274.

Bolton, Ruth N. and Shruti Saxena-Iyer (2009), "Interactive Services: A Framework, Synthesis and Research Directions," Journal of Interactive Marketing, 23, 1, 91-104.

Bowden, Jana L. (2009), “The Process of Customer Engagement: A Conceptual Framework,’ Journal of Marketing Theory and Practice, 17, 1, 63-74.

Boyd, Danah M. and Nicole B. Ellison (2008), "Social Network Sites: Definition, History, and Scholarship," Journal of Computer-Mediated Communication, 13, 1, 210-230.

Brakus, Josko J., Bernd H. Schmitt and Lia Zarantello (2009), "Brand Experience: What Is It? How Is It Measured? Does It Affect Loyalty?," Journal of Marketing, 73, 3, 52-68.

Briggs, Tom (2010), “Social Media's Second Act: Toward Sustainable Brand Engagement," Design Management Review, 21, 1, 46-53.

Brodie, Roderick J., Linda D. Hollebeek, Biljana Juric and Ana Ilic (2011), "Customer Engagement: Conceptual Domain, Fundamental Propositions \& Implications for Research in Service Marketing," Journal of Service Research, 14, 3, 252-271. 
Brodie, Roderick J., Ana Ilic, Biljana Juric and Linda D. Hollebeek (2013), "Consumer Engagement in a Virtual Brand Community: An Exploratory Analysis," Journal of Business Research, 66, 1, 105-114.

Brown, Tom J., Peter A. Dacin, Michael G. Pratt and David A. Whetten (2006), "Identity, Intended Image, Construed Image, and Reputation: An Interdisciplinary Framework and Suggested Terminology," Journal of the Academy of Marketing Science, 34, 2, 99-106.

Byrne, Barbara M. (2010), “Structural Equation Modeling with Amos: Basic Concepts, Applications, and Programming, 2e, New York: Routledge.

Byrne, Dara N. (2008), "Public Discourse, Community Concerns, and Civic Engagement: Exploring Black Social Networking Traditions on BlackPlanet.com," Journal of Computer-Mediated Communication, 13, 1, 319-340.

Calder, Bobby J., Edward M. Malthouse and Ute Schaedel (2009), "An Experimental Study of the Relationship between Online Engagement and Advertising Effectiveness," Journal of Interactive Marketing, 23, 4, 321-331.

Cattell, Raymond B. (1966), "The Scree Test for the Number of Factors," Multivariate Behavioral Research, 1, 2, 245276.

Churchill, Gilbert A., Jr. (1979), “A Paradigm for Developing Better Measures of Marketing Constructs,” Journal of Marketing Research, 16, 1, 64-73.

Cohen, Jacob (1988), Statistical Power Analysis for the Behavioral Sciences, 2e, Hillsdale, NJ: Lawrence Erlbaum Associates.

Conway, James M. and Allen I. Huffcut (2003), "A Review and Evaluation of Exploratory Factor Analysis Practices in Organizational Research,” Organizational Research Methods, 6, 2, 147-168.

Coulter, Robin, Linda Price and Lawrence Feick (2003), "Rethinking the Origins of Involvement and Brand Commitment: Insights from Postsocialist Europe," Journal of Consumer Research, 30, 2, 151-169.

De Valck, Kristine, Gerrit H. Van Bruggen and Berend Wierenga (2009), "Virtual Communities: A Marketing Perspective," Decision Support Systems, 47, 3, 185-203.

Escalas, Jennifer E. (2004), "Narrative Processing: Building Consumer Connections to Brands," Journal of Consumer Psychology, 14, 1-2, 168-180.

Escalas, Jennifer E. and James R. Bettman (2005), “Self-Construal, Reference Groups and Brand Meaning,” Journal of Consumer Research, 32, 3, 378-389.

Fishbein, Martin and Icek Ajzen (1975), Belief, Attitude, Intention, and Behavior: An Introduction to Theory and Research, Reading, Mass.: Addison-Wesley Publishing Co.

Fornell, Claes and David F. Larcker (1981a), "Evaluating Structural Equation Models with Unobservable Variables and Measurement Error," Journal of Marketing Research, 18, 1, 39-50.

Fornell, Claes and David F. Larcker (1981b, "Structural Equation Models with Unobservable Variables and Measurement Error: Algebra and Statistics," Journal of Marketing Research, 18, 3, 382-388.

Fournier, Susan M. (1998), "Consumers and Their Brands: Developing Relationship Theory in Consumer Research," Journal of Consumer Research, 24, 4, 343-353.

Fournier, Susan M. and Jill Avery (2011), “The Uninvited Brand,” Business Horizons, 54, 3, 193-207.

Grönroos, Christian (2006), "Adopting a Service Logic for Marketing, Marketing Theory, 6, 3, 317-333.

Grönroos, Christian and P. Voima (2012), "Critical Service Logic: Making Sense of Value Creation and Co-Creation," Journal of the Academy of Marketing Science, In press, DOI: 10.1007/s11747-012-0308-3.

Gustaffson, Anders, Michael D. Johnson, and Inger Roos (2005), "The Effects of Customer Satisfaction, Relationship Commitment Dimensions, and Triggers on Customer Retention," Journal of Marketing, 69, 4, 210-218.

Hair, Joseph F. Jr., William C. Black, Barry J. Babin and Rolph E. Anderson (2010), "Multivariate Data Analysis: A Global Perspective," 7e, London: Pearson Education.

Hennig-Thurau, Thorsten, Edward C. Malthouse, Christian Friege, Sonja Gensler, Lara Lobschat, Arvind Rangaswamy and Bernd Skiera (2010), "The Impact of New Media on Customer Relationships," Journal of Service Research, 13, 3, 311-330.

Higgins, E. Tory (2006), "Value from Hedonic Experience and Engagement," Psychological Review, 113, 3, 439-460.

Higgins, E. Tory and Abigail A. Scholer (2009), "Engaging the Consumer: The Science and Art of the Value Creation Process," Journal of Consumer Psychology, 19, 2, 100-114.

Hildebrandt, Lutz (1987), "Consumer Retail Satisfaction in Rural Areas: A Reanalysis of Survey Data," Journal of Economic Psychology, 8, 1, 19-42. 
Hoffman, Donna L. and Thomas P. Novak (1996), "Marketing in Hypermedia Computer-Mediated Environments: Conceptual Foundations," Journal of Marketing, 60, July, 50-68.

Hoffman, Donna L. and Thomas P. Novak (2012), “Toward a Deeper Understanding of Social Media," Journal of Interactive Marketing, 26, 69-70.

Hollebeek, Linda D. (2011a), "Demystifying Customer Brand Engagement: Exploring the Loyalty Nexus," Journal of Marketing Management, 27, 7-8, 785-807.

Hollebeek, Linda D. (2011b), "Exploring Customer Brand Engagement: Definition and Themes," Journal of Strategic Marketing, 19, 7, 555-573.

Hollebeek, Linda D. (2012), “The Customer Engagement/Value Interface: An Exploratory Investigation,” Australasian Marketing Journal, 21 (1), 17-24.

Iacobucci, Dawn (2010), “Structural Equations Modeling: Fit Indices, Sample Size and Advanced Topics," Journal of Consumer Psychology, 20, 1, 90-98.

Johnson, Michael D. and Claes Fornell (1991), "A Framework for Comparing Customer Satisfaction across Individuals and Product Categories," Journal of Economic Psychology, 12, 2, 267-286.

Kaplan, Andreas M. and Michael Haenlein (2010), "Users of the World, Unite! The Challenges and Opportunities of Social Media," Business Horizons, 53, 1, 59-68.

Karpen, Ingo O., Liliana L. Bove and Bryan A. Lukas (2012), "Linking Service-Dominant Logic and Strategic Business Practice: A Conceptual Model of a Service-Dominant Orientation," Journal of Service Research, 15, 1, 21-38.

Keller, Kevin L. (1993), “Conceptualizing, Measuring and Managing Customer-Based Brand Equity,” Journal of Marketing, 57, 1, 1-22.

Kumar, V. Lerzan Aksoy, Bas Donkers, Rajkumar Venkatesan, Thorsten Wiesel and Sebastian Tillmanns (2010), "Undervalued or Overvalued Customers: Capturing Total Customer Engagement Value," Journal of Service Research, 13, 3, 297-310.

Leeflang, Peter (2011), "Paving the Way for Distinguished Marketing," International Journal of Research in Marketing, 28, 2, 76-88.

Leeflang, Peter, Tammo Bijmolt, Jenny Van Doorn, Dominique M. Hanssens, Harald Van Heerde, Peter C. Verhoef and Wierenga, J. (2009). Creating Lift Versus Building Base: Current Trends in Marketing Dynamics," International Journal of Research in Marketing, 26, 1, 13-20.

Lemke, Fred, Moira Clark and Hugh Wilson (2011), "Customer Experience Quality: An Exploration in Business and Consumer Contexts Using Repertory Grid Technique,” Journal of the Academy of Marketing Science, 39, 6, 846-869.

Libai, Barak R. (2011), “The Perils of Focusing on Highly Engaged Customers," Journal of Service Research, 14, 3, 275-276.

Malthouse, Edward and Charles Hofacker (2010), "Looking Back and Looking Forward with Interactive Marketing," Journal of Interactive Marketing, 24, 3, 181-184.

Marsh, Herbert W., Kit Tau Hau and Zhonglin Wen (2004), "In Search of Golden Rules: Comment on HypothesisTesting Approaches to Setting Cutoff Values for Fit Indexes and Dangers in Overgeneralizing Hu and Bentler's (1999) Findings," Structural Equation Modeling: A Multidisciplinary Journal, 11, 3, 320-341.

Menard, Scott (2002), “Longitudinal Research,” 2e, Quantitative Applications in the Social Sciences, 2e, No. 76, Thousand Oaks: Sage Publications.

Mittal, Banwari (1995), “A Comparative Analysis of Four Scales of Consumer Involvement," Psychology \& Marketing, $12,7,663-682$.

Mittal, Vikas, Pankaj Kumar and Michael Tsiros (1999), “Attribute-Level Performance, Satisfaction, and Behavioral Intentions over Time: A Consumption-System Approach, Journal of Marketing, 63 (2), 88-101.

Mollen, Anne and Hugh Wilson (2010), "Engagement, Telepresence, and Interactivity in Online Consumer Experience: Reconciling Scholastic and Managerial Perspectives," Journal of Business Research, 63, 9/10, 919-925.

MSI - Marketing Science Institute (2010), “2010-2012 Research Priorities,” Retrieved from: http://www.msi.org/research/index.cfm?id=271 (October 3, 2013).

Nambisan, Satish and Robert A. Baron (2007), "Interactions in Virtual Customer Environments: Implications for Product Support and Customer Relationship Management," Journal of Interactive Marketing, 21, 2, 42-62. 
Pagani, Margherita, Charles F. Hofacker, and Ronald E. Goldsmith (2011), "The Influence of Personality on Active and Passive Use of Social Networking Sites," Psychology \& Marketing, 28, 5, 441-456.

Patterson, Paul, Ting Yu and Ko De Ruyter (2006), “Understanding Customer Engagement in Services,” AZMAC Proceedings, Brisbane.

Pham, Michel T. and Tamar Avnet (2009), "Rethinking Regulatory Engagement Theory,” Journal of Consumer Psychology, 19, 2, 115-123.

Phillips, Barbara J. and Edward F. McQuarrie (2010), "Narrative and Persuasion in Fashion Advertising," Journal of Consumer Research, 37, 3, 368-392.

Prahalad, Coimbatore K. (2004), "The Co-Creation of Value: Invited Commentaries on "Evolving to a New Dominant Logic for Marketing,” Journal of Marketing, 68, 1, 23.

Preacher, Kristopher J. and Andrew F. Hayes (2008), "Asymptotic and Resampling Strategies for Assessing and Comparing Indirect Effects in Multiple Indicator Models," Behavior Research Methods, 40, 3, 879-891.

Ramani, G. and Kumar, V. (2008). Interaction orientation and firm performance. Journal of Marketing, 72, 1, 27-45.

Rindfleisch, Aric, James A. Burroughs, J.A. and Nancy Wong (2009), "The Safety of Objects: Materialism, Existential Security, and Brand Connection," Journal of Consumer Research, 36, 1, 1-16.

Russell, Matthew A. (2011), "Mining the Social Web: Analyzing Data from Facebook, Twitter, LinkedIn and Other Social Media Sites,” Sebastopol, CA: O’Reilly Media, Inc.

Sawhney, Mohanbir, Gianmario Verona and Emanuela Prandelli (2005), "Collaborating to Create: The Internet as a Platform for Customer Engagement in Product Innovation," Journal of Interactive Marketing, 19, 4, 4-17.

Scarpi, Daniele (2012), "Work and Fun on the Internet: The Effects of Utilitarianism and Hedonism Online," Journal of Interactive Marketing, 26, 53-67.

Schau, Hope J., Albert M. Muñiz, Jr. and Eric J. Arnould (2009), “How Brand Communities Create Value,” Journal of Marketing, 73, 5, 30-51.

Shankar, Venkatesh and Rajeev Batra (2009), “The Growing Influence of Online Marketing Communications,” Journal of Interactive Marketing, 23, 285-287.

Singh, Sangeeta and Stephan Sonnenburg (2012), "Brand Performances in Social Media," Journal of Interactive Marketing, 26, 189-197.

Sprott, David, Sandor Czellar and Eric Spangenberg (2009), „The Importance of a General Measure of Brand Engagement on Market Behavior: Development and Validation of a Scale," Journal of Marketing Research, $46,1,92-104$.

Steenkamp, Jan-Benedict E.M and Hans Baumgarter (2000), "On the Use of Structural Equation Models for Marketing Modeling," International Journal of Research in Marketing, 17, 2-3, 195-202.

Steenkamp, Jan-Benedict E.M. and Hans C.M. Van Trijp (1991), "The Use of LISREL in Validating Marketing Constructs," International Journal of Research in Marketing, 8, 4, 283-299.

Steiger, James H. (1990), "Structural Model Evaluation and Modification: An Interval Estimation Approach," Multivariate Behavioral Research, 25, 2, 173-180.

Stern, Barbara (2006), "What Does 'Brand' Mean? Historical Analysis Method and Construct Definition," Journal of the Academy of Marketing Science, 34, 2, 216-223.

Van Doorn, Jenny, Katherine E. Lemon, Vikas Mittal, Stephan Naß, Doréen Pick, Peter Pirner and Peter C. Verhoef (2010), "Customer Engagement Behavior: Theoretical Foundations and Research Directions," Journal of Service Research, 13, 3, 253-266.

Van Laer, Tom, Ko De Ruyter and David Cox (2013), “A Walk in Customers' Shoes: How Attentional Bias Modification Affects Ownership of Integrity-Violating Social Media Posts," Journal of Interactive Marketing, 27, 14-27.

Vargo, Stephen L. and Robert F. Lusch (2004), “Evolving to a New Dominant Logic for Marketing,” Journal of Marketing, 68, 1, 1-17.

Vargo, Stephen L. and Robert F. Lusch (2008a), "Service-Dominant Logic: Continuing the Evolution," Journal of the Academy of Marketing Science, 36, 1, 1-10.

Verhoef, Peter C., Werner Reinartz and Manfred Krafft (2010), Customer Engagement as a New Perspective in Customer Management," Journal of Service Research, 13, 3, 247-252. 
Vivek, Shiri, Sharon E. Beatty and Robert Morgan (2012), "Customer Engagement: Exploring Customer Relationships beyond Purchase," Journal of Marketing Theory \& Practice, 20, 2, 122-146.

Voss, Kevin E., Eric R. Spangenberg and Bianca Grohmann (2003), "Measuring Hedonic and Utilitarian Dimensions of Consumer Attitude," Journal of Marketing Research, 40, 3, 310-320.

Yoo, Boonghee and Naveen Donthu (2001), "Developing and Validating a Multidimensional Consumer-Based Brand Equity Scale," Journal of Business Research, 52, 1, 1-14.

Zaichkowsky, Judith L. (1985), "Measuring the Involvement Construct,” Journal of Consumer Research, 12, 3, 341362.

Zaichkowsky, Judith L. (1994), The Personal Involvement Inventory: Reduction, Revision, and Application to Advertising," Journal of Advertising, 23, 4, 59-70.

Zhao, Xinshu, John G. Lynch, Jr., and Qimei Chen (2010), "Reconsidering Baron and Kenny: Myths and Truths about Mediation Analysis," Journal of Consumer Research, 37, 2, 197-206. 
Table 1: Overview - Engagement Conceptualizations in the Marketing Literature

\begin{tabular}{|c|c|c|c|c|}
\hline Author(s) & $\begin{array}{l}\text { Research } \\
\text { Type }\end{array}$ & Concept & Definition & Dimensionality \\
\hline $\begin{array}{l}\text { Brodie et al. } \\
(2011)\end{array}$ & Conceptual & $\begin{array}{l}\text { Customer } \\
\text { engagement }\end{array}$ & $\begin{array}{l}\text { A motivational state that occurs by virtue of interactive, co-creative } \\
\text { customer experiences with a focal agent/object (e.g. a brand) in } \\
\text { focal brand relationships. }\end{array}$ & $\begin{array}{l}\text { Multidimensional: } \\
\text { 1. Cognitive; 2. Emotional; 3. Behavioral }\end{array}$ \\
\hline $\begin{array}{l}\text { Hollebeek } \\
\text { (2011a) }\end{array}$ & Conceptual & $\begin{array}{l}\text { Customer } \\
\text { brand } \\
\text { engagement }\end{array}$ & $\begin{array}{l}\text { The level of an individual customer's motivational, brand-related } \\
\text { and context-dependent state of mind characterized by specific } \\
\text { levels of cognitive, emotional and behavioral activity in brand } \\
\text { interactions. }\end{array}$ & $\begin{array}{l}\text { Multidimensional: } \\
\text { 1. Cognitive; 2. Emotional; 3. Behavioral }\end{array}$ \\
\hline $\begin{array}{l}\text { Hollebeek } \\
(2011 b)\end{array}$ & $\begin{array}{l}\text { Empirical: } \\
\text { Qualitative }\end{array}$ & $\begin{array}{l}\text { Customer } \\
\text { brand } \\
\text { engagement }\end{array}$ & $\begin{array}{l}\text { A customer's level of cognitive, emotional and behavioral } \\
\text { investment in specific brand interactions. }\end{array}$ & $\begin{array}{l}\text { Multidimensional: } \\
\text { 1. Cognitive; 2. Emotional; 3. Behavioral }\end{array}$ \\
\hline $\begin{array}{l}\text { Phillips and } \\
\text { McQuarrie } \\
(2010)\end{array}$ & $\begin{array}{l}\text { Empirical: } \\
\text { Qualitative }\end{array}$ & $\begin{array}{l}\text { Advertising } \\
\text { engagement }\end{array}$ & 'Modes of engagement' are routes to persuasion. & $\begin{array}{l}\text { Multidimensional: } \\
\text { Consumers engage ads to: } 1 \text {. Immerse (C); } \\
\text { 2. Feel (E); 3. Identify (E); 4. Act (B) }\end{array}$ \\
\hline $\begin{array}{l}\text { Brodie et al. } \\
(2013)\end{array}$ & $\begin{array}{l}\text { Empirical: } \\
\text { Qualitative }\end{array}$ & $\begin{array}{l}\text { Consumer } \\
\text { engagement }\end{array}$ & $\begin{array}{l}\text { A multidimensional concept comprising cognitive, emotional, } \\
\text { and/or behavioral dimensions, [which] plays a central role in the } \\
\text { process of relational exchange where other relational concepts are } \\
\text { engagement antecedents and/or consequences in iterative } \\
\text { engagement processes within the brand community. }\end{array}$ & $\begin{array}{l}\text { Multidimensional: } \\
\text { 1. Cognitive; 2. Emotional; 3. Behavioral }\end{array}$ \\
\hline $\begin{array}{l}\text { Calder et al. } \\
(2009)\end{array}$ & $\begin{array}{l}\text { Empirical: } \\
\text { Quantitative }\end{array}$ & $\begin{array}{l}\text { Online } \\
\text { engagement }\end{array}$ & $\begin{array}{l}\text { A second-order construct manifested in various types of first-order } \\
\text { 'experience' constructs, with 'experience' being defined as "a } \\
\text { consumer's beliefs about how a (web)site fits into his/her life." }\end{array}$ & $\begin{array}{l}\text { Multidimensional: } \\
\text { 1. Stimulation \& inspiration (E); 2. Social } \\
\text { facilitation (E); 3. Temporal (C); 4. Self- } \\
\text { esteem \& civic mindedness (E); } 5 \text {. } \\
\text { Intrinsic enjoyment (E); 6. Utilitarian (C); } \\
\text { 7. Participation \& socializing (B); 8. } \\
\text { Community (E) }\end{array}$ \\
\hline $\begin{array}{l}\text { Avnet and } \\
\text { Higgins } \\
(2006 a)\end{array}$ & Conceptual & Engagement & $\begin{array}{l}\text { When people pursue a goal in a manner that sustains their } \\
\text { orientation (e.g. eagerly if they have a promotion focus; vigilantly if } \\
\text { they have a prevention focus), they experience their engagement in } \\
\text { that goal pursuit more strongly than they do when pursuing the goal } \\
\text { in a way that is at odds with or disrupts their orientation (e.g. } \\
\text { pursuing a goal eagerly if their orientation is more preventative). } \\
\text { When the manner of their goal pursuit fits their orientation, they } \\
\text { experience a stronger evaluative reaction to the activity. }\end{array}$ & $\begin{array}{l}\text { Multi-dimensional (inferred): } \\
\text { 1. Cognitive; 2. Emotional; 3. Behavioral }\end{array}$ \\
\hline Algesheimer & Empirical: & Brand & Positive influences of identifying with the brand community & Multidimensional: \\
\hline
\end{tabular}




\begin{tabular}{lllll}
\hline Author(s) & $\begin{array}{l}\text { Research } \\
\text { Type }\end{array}$ & Concept & Definition & Dimensionality \\
\hline et al. (2005) & Quantitative & $\begin{array}{l}\text { community } \\
\text { engagement }\end{array}$ & $\begin{array}{l}\text { through the consumer's intrinsic motivation to interact/co-operate } \\
\text { with community members. }\end{array}$ & $\begin{array}{l}\text { 1. Utilitarian (C); 2. Hedonic (E); 3. Social } \\
\text { (B/E) }\end{array}$ \\
\hline $\begin{array}{l}\text { Abdul-Ghani } \\
\text { et al. (2010) }\end{array}$ & $\begin{array}{l}\text { Empirical: } \\
\text { Qualitative }\end{array}$ & Engagement & Requires consumer connection (e.g. with specific media). & $\begin{array}{l}\text { Multidimensional: } \\
1 . \text { Utilitarian (C); 2. Hedonic (E); 3. Social } \\
\text { (B/E) }\end{array}$ \\
\hline $\begin{array}{lllll}\text { Sprott et al. } \\
(2009)\end{array}$ & Empirical & $\begin{array}{l}\text { Brand } \\
\text { engagement } \\
\text { in self- } \\
\text { concept }\end{array}$ & $\begin{array}{l}\text { An individual difference representing consumers' propensity to } \\
\text { include important brands as part of how they view themselves. }\end{array}$ & Unidimensional (E) \\
\hline This study & Empirical & $\begin{array}{l}\text { Consumer } \\
\text { brand } \\
\text { engagement }\end{array}$ & $\begin{array}{l}\text { A consumer's positively valenced cognitive, emotional and Multidimensional (*): } \\
\text { behavioral brand-related activity during, or related to, specific } \\
\text { consumer/brand interactions. }\end{array}$ & $\begin{array}{l}1 . \text { Cognitive processing (C); 2. Affection } \\
\text { (E); 3. Activation (B) }\end{array}$
\end{tabular}

Notes - Proposed 'engagement' dimensionality: C: Cognitive; E: Emotional; B: Behavioral; $(*)$ : The proposed engagement dimensionality was determined in the course of the scale development procedures, rather than pre-determined before conducting the analyses. 
Table 2: Respondents' Self-Selected Brands in Qualitative Research (Study 1)

\begin{tabular}{|c|c|}
\hline Informant & Highly Engaging Brand \\
\hline \multirow{4}{*}{$\begin{array}{l}\text { 1. Andrew } \\
\text { (39) }\end{array}$} & The Amazing Race (Reality television show) \\
\hline & $\begin{array}{l}\text { The episodes [The Amazing Race] are an hour long, but it seems like you've only watched } \\
\text { five minutes; time just flies by. [When watching the show] I'm totally excluding other } \\
\text { stuff. }\end{array}$ \\
\hline & I've always been a bit mad for [The Amazing Race]; passionate even. \\
\hline & $\begin{array}{l}\text { Sunday night } 7.30 \text { I'm there [for The Amazing Race]. And if I'm not, I've got to record it; } \\
\text { [or] I'm hunting down the Internet to find that episode. I've [also] put it onto my Facebook } \\
\text { page. }\end{array}$ \\
\hline \multirow[t]{4}{*}{ 2. Joan (34) } & Kinder Chocolate (FMCG) \\
\hline & [With Kinder Chocolate] I can just forget my environment; I can really relax. \\
\hline & [Kinder Chocolate] is the chocolate for me; it's just part of my life. \\
\hline & $\begin{array}{l}\text { [I'll get Kinder Chocolate from anywhere I can]; I recently bought it at [the] airport when I } \\
\text { was travelling. }\end{array}$ \\
\hline
\end{tabular}

\section{Eve (65) Mercedes-Benz (Automobile)}

[Time flies when] I think about my next [Mercedes-Benz]... the detail, design, [the] specs.

I love Mercs. My heart's with Merc!

I've spent quite a bit of time on the Internet looking at my next [Mercedes-Benz]; the design, from different angles.

\section{Ben (54) H\&S Gym (Gymnasium)}

Everything linked to the brand is tying in with [me] trying...to stay fit and healthy; the brand is H\&S. I'm constantly thinking about that.

I want to be there [at H\&S Gym]; it's the one sticker I have on my car. There is a sense of pride with it.

I have a strict [H\&S Gym] routine; making sure I get there every second night, and trying to make my full hour. [And] I'll talk about this gym [with others].

5.

Anna (30)

\section{The Body Shop (Cosmetics)}

I'm really absorbed by [The Body Shop products].

I love [The Body Shop] products and the feel-good aspect of it. I have a smile on my face

\section{BP (Retail petrol chain)}

[BP] raid and pillage the planet to further their commercial goals. I ... don't feel like I can identify with them at all.

I don't bring up petrol buying, I don't talk about where I buy my petrol [from with others].

\section{Unidentified brand (Stationery)}

When I buy pens and pencils I [don't] mind what brand they are. It's important that it's cheap and affordable... It doesn't really matter what brand I buy.

There is a function, [I] want to write with it, but there's really not a lot about it, what it can do for me.

\section{Nivea (Cosmetics)}

I don't get excited about [Nivea], it just gets thrown on.

[With Nivea] there's none of that psychological connection at all. It's functional, and it will do the job, for the time being.

\section{National Bank (Retail bank)}

[The National Bank] is meeting a need. It's like going to a doctor or a dentist; they are not necessarily things you want to do, whereas I want to go to [H\&S] Gym.

When I'm engaging with the [bank] staff, it's like just going through the motions, through the routine... I can't be bothered to answer all the questions, they have for me. Whereas at [H\&S] Gym, I will genuinely be talking to the staff, genuinely interested in them, and what they are all about.

\section{Foodtown (Supermarket)}

I don't really look forward to [going to Foodtown], it's just a purely utilitarian thing... It doesn't really matter [which 
in the morning when [I] put on [my] moisturizer.

Last week [The Body Shop] didn't have an item I wanted; [So] I'll come back later .... and get it when it's back in stock. I'm not [going] to some other store.

\section{Jake (20) Apple iPod (Consumer electronics)}

[My iPod] can take up all my attention.

I'm a [Apple iPod] fan! Can't do without. It's a great product.

I use [Apple iPod] all the time, chat about it with my friends, and am always looking for the latest updates and iTunes.

\section{Rose Disney (Family entertainment)}

That hour-and-a-half in front of that Disney movie is 'gone' [just like that].

[I love Disney]; it's sheer happiness.

If there's a new Disney movie, we're there! I [also] talk about [Disney] concepts with my kids.

\section{Gerald Qantas (Airline)}

(61) I know if I'm on a Qantas flight, I'm going to get there. Safely.

I'm passionate about Qantas. If I'm seen walking off another branded plane, I feel shame.

I won't fly anybody else; [and] I won't have a bad word spoken about Qantas.

\section{Miranda Givenchy (Luxury cosmetics)}

(52) I always think [Givenchy] looks so much better than the competing brands.

I hold [Givenchy] very dear to me. It gives me a special feeling.

[Recently] I was one of the first to [get Givenchy limited edition perfumes] because they had a very limited amount. I ended up with quite a big bill.

\section{Rachel Country Road (Clothing)}

(48)

[At Country Road] I feel I'm having an experience. The store has a nice atmosphere, the clothes feel special, they relate to ... my desired personality.

[I] can spend quite a lot of time in the [Country Road] store. I'll look at the men's wear, even though my husband won't wear it, as well as the women's wear.

\section{supermarket I go to].}

Foodtown is not a place where I would go and browse. It's not the experience [I] go for, [I] just [go there] because [I] need food for the week. While I'll go around and browse in The Body Shop and try some creams on my hands, and see whether I like the scent.

\section{Burgen Bread (FMCG)}

With Bürgen Bread I just want to get the purchase over with as soon as possible, just so that I have bread in the house for the next meal.

\section{Caltex (Retail petrol chain)}

I buy [petrol] from Caltex because it is conveniently situated. If the [would be] selling that station to someone else, then I wouldn't care... My attitude to categories like groceries and petrol, I don't have a choice, I need to be mobile, I need to feed my family.

\section{Blue (Mineral water/FMCG)}

I only buy [it if it's] on special... It's got to be less than $\$ 2$ a bottle, then I'll buy it.

\section{Philips (Consumer electronics)}

We have always bought Philips, like TVs, video players and DVDs. We still have a Philips TV... we have a Philips video, DVD, but I'm not overly impressed with it.

\section{Holeproof (Socks)}

I see [socks] as a functional purchase, not an emotional purchase. And that's why I would continue to engage with, let's say... Hole Proof, so it would still be of consistent quality, but it lacks meaning.

\footnotetext{
Note - The sample comprised 10 informants from different areas in a large Pacific Coast city, aged 20-68, seven of whom were male.
} 
Table 3: Consumer Brand Engagement - Descriptive Statistics (Study 3)

\begin{tabular}{lccc}
\hline & Cognitive Processing & Affection & Activation \\
\hline Cognitive Processing & $\mathbf{. 6 2}$ & .74 & .50 \\
\hline Affection & .86 & .71 & .67 \\
\hline Activation & .71 & .82 & .74 \\
\hline Mean & 4.19 & 4.60 & 4.01 \\
\hline Std. Dev. & 1.26 & 1.17 & 1.55 \\
\hline
\end{tabular}

Notes - Bivariate correlations between the constructs, which are significant at $p<0.01 ; A V E s$ are shown on the diagonal (in bold); Squared correlations are shown above the diagonal; Correlations are shown below the diagonal; $n=554$. 
Table 4: Measures \& Selected Statistics for Model Constructs (Study 4)

\begin{tabular}{|c|c|c|c|c|c|c|c|}
\hline Construct & Source & $\alpha$ & $\mathbf{C R}$ & Item & Item Description & Mean & SD \\
\hline \multirow{10}{*}{$\begin{array}{l}\text { 1. Consumer } \\
\text { involvement } \\
\text { (INV.) }\end{array}$} & \multirow{10}{*}{$\begin{array}{l}\text { Zaichkowsky } \\
\text { (1994) }\end{array}$} & \multirow[t]{10}{*}{.938} & \multirow[t]{10}{*}{.896} & INV1 & Unimportant - Important & 4.3 & 1.4 \\
\hline & & & & INV2 & Boring - Interesting & 4.5 & 1.3 \\
\hline & & & & INV3 & Irrelevant - Relevant & 4.9 & 1.3 \\
\hline & & & & INV4 & Unexciting - Exciting & 4.1 & 1.3 \\
\hline & & & & INV5 & Means nothing - Means a lot to me & 4.3 & 1.2 \\
\hline & & & & INV6 & Unappealing - Appealing & 4.5 & 1.3 \\
\hline & & & & INV7 & Mundane - Fascinating & 4.2 & 1.2 \\
\hline & & & & INV8 & Worthless - Valuable & 4.9 & 1.2 \\
\hline & & & & INV9 & Uninvolving - Involving & 4.5 & 1.3 \\
\hline & & & & INV10 & Not needed - Needed & & \\
\hline \multirow{5}{*}{$\begin{array}{l}\text { 2. CBE 'cognitive } \\
\text { processing' factor } \\
\text { (COG. PROC.) }\end{array}$} & \multirow[t]{5}{*}{ Newly developed } & \multirow[t]{5}{*}{.878} & \multirow[t]{5}{*}{.781} & $\mathrm{CP} 1$ & $\begin{array}{l}\text { Using LinkedIn.com gets me to think } \\
\text { about LinkedIn.com. }(*)\end{array}$ & 4.1 & 1.4 \\
\hline & & & & $\mathrm{CP} 2$ & $\begin{array}{l}\text { I think about LinkedIn.com a lot when } \\
\text { I'm using it. }(*)\end{array}$ & 3.8 & 1.4 \\
\hline & & & & $\mathrm{CP} 3$ & Using LinkedIn.com stimulates my & 4.0 & 1.4 \\
\hline & & & & & interest to learn more about & & \\
\hline & & & & & LinkedIn.com. (*) & & \\
\hline \multirow[t]{4}{*}{$\begin{array}{l}\text { 3. CBE 'affection' } \\
\text { factor (AFFEC.) }\end{array}$} & \multirow[t]{4}{*}{ Newly developed } & \multirow[t]{4}{*}{.928} & \multirow[t]{4}{*}{.873} & AF1 & $\begin{array}{l}\text { I feel very positive when I use } \\
\text { LinkedIn.com. }(*)\end{array}$ & 4.3 & 1.4 \\
\hline & & & & AF2 & $\begin{array}{l}\text { Using LinkedIn.com makes me happy. } \\
(*)\end{array}$ & 3.9 & 1.3 \\
\hline & & & & AF3 & $\begin{array}{l}\text { I feel good when I use LinkedIn.com. } \\
(*)\end{array}$ & 4.0 & 1.3 \\
\hline & & & & AF4 & I'm proud to use LinkedIn.com. (*) & 4.3 & 1.3 \\
\hline \multirow[t]{3}{*}{$\begin{array}{l}\text { 4. CBE 'activation' } \\
\text { factor (ACTIV.) }\end{array}$} & \multirow[t]{3}{*}{ Newly developed } & \multirow[t]{3}{*}{.857} & \multirow[t]{3}{*}{.713} & $\mathrm{AC} 1$ & $\begin{array}{l}\text { I spend a lot of time using } \\
\text { LinkedIn.com, compared to other } \\
\text { professional social networking sites. }(*)\end{array}$ & 3.8 & 1.7 \\
\hline & & & & $\mathrm{AC} 2$ & $\begin{array}{l}\text { Whenever I'm using professional social } \\
\text { networking sites, I usually use } \\
\text { LinkedIn.com. }(*)\end{array}$ & 4.8 & 1.5 \\
\hline & & & & $\mathrm{AC} 3$ & $\begin{array}{l}\text { LinkedIn.com is one of the brands I } \\
\text { usually use when I use professional } \\
\text { social networking sites. }(*)\end{array}$ & 4.8 & 1.5 \\
\hline
\end{tabular}




\begin{tabular}{|c|c|c|c|c|c|c|c|}
\hline Construct & Source & $\alpha$ & $\mathbf{C R}$ & Item & Item Description & Mean & SD \\
\hline \multirow[t]{7}{*}{$\begin{array}{l}\text { 5. Self-brand } \\
\text { connection (SBC) }\end{array}$} & Escalas (2004) & .926 & .869 & SBC1 & LinkedIn.com reflects who I am. $(*)$ & 3.9 & 1.4 \\
\hline & & & & SBC2 & I can identify with LinkedIn.com. $(*)$ & 4.2 & 1.3 \\
\hline & & & & SBC3 & $\begin{array}{l}\text { I feel a personal connection to } \\
\text { LinkedIn.com. }(*)\end{array}$ & 3.7 & 1.4 \\
\hline & & & & SBC4 & $\begin{array}{l}\text { I use LinkedIn.com to communicate } \\
\text { who I am to other people. }\end{array}$ & 4.4 & 1.4 \\
\hline & & & & SBC5 & $\begin{array}{l}\text { I think LinkedIn.com (could) help(s) me } \\
\text { become the type of person I want to be. }\end{array}$ & 3.7 & 1.6 \\
\hline & & & & SBC6 & $\begin{array}{l}\text { I consider LinkedIn.com to be 'me' (It } \\
\text { reflects who I consider myself to be or } \\
\text { the way that I want to present myself to } \\
\text { other(s). }\end{array}$ & 3.7 & 1.6 \\
\hline & & & & SBC7 & LinkedIn.com suits me well. $(*)$ & 4.3 & 1.4 \\
\hline \multirow[t]{4}{*}{$\begin{array}{l}\text { 6. Brand usage intent } \\
\text { (BUI) }\end{array}$} & $\begin{array}{l}\text { Yoo and } \\
\text { Donthu } \\
\text { (2001) }\end{array}$ & .926 & .884 & BUI1 & $\begin{array}{l}\text { It makes sense to use LinkedIn.com } \\
\text { instead of any other brand, even if they } \\
\text { are the same. }(*)\end{array}$ & 4.4 & 1.3 \\
\hline & & & & BUI2 & $\begin{array}{l}\text { Even if another brand has the same } \\
\text { features as LinkedIn.com, I would prefer } \\
\text { to use LinkedIn.com. }\left({ }^{*}\right)\end{array}$ & 4.5 & 1.3 \\
\hline & & & & BUI3 & $\begin{array}{l}\text { If there is another brand as good as } \\
\text { LinkedIn.com, I prefer to use } \\
\text { LinkedIn.com. }(*)\end{array}$ & 4.4 & 1.3 \\
\hline & & & & BUI4 & $\begin{array}{l}\text { If another brand is not different from } \\
\text { LinkedIn.com in any way, it seems } \\
\text { smarter to use LinkedIn.com. }(*)\end{array}$ & 4.6 & 1.3 \\
\hline
\end{tabular}

Notes - $n=556 ; \alpha$ : Cronbach's alpha; CR: Construct reliability; Items marked with asterisk (*): Employed in structural equation modeling analyses (based on CFA results undertaken for individual constructs; cf. Preliminary Results sub-section, study 3); BUI scale drawn from Yoo \& Donthu's (2001) 'overall brand equity' measurement instrument; Items measured on 7-point Likert scales (except INV: 7-point semantic-differential scale); The higher the rating, the more favorable; SD: Standard deviation; $\alpha$ (Overall CBE scale $)=.943$. 
Table 5: Discriminant Validity - All Constructs (Study 4)

\begin{tabular}{|c|c|c|c|c|c|c|}
\hline & Involvement & $\begin{array}{c}\text { Cognitive } \\
\text { Processing }\end{array}$ & Affection & Activation & $\begin{array}{l}\text { Self-Brand } \\
\text { Connection }\end{array}$ & $\begin{array}{c}\text { Brand Usage } \\
\text { Intent }\end{array}$ \\
\hline Involvement & .71 & .47 & .70 & .52 & .70 & .45 \\
\hline $\begin{array}{l}\text { Cognitive } \\
\text { Processing }\end{array}$ & .69 & .70 & .71 & .45 & .55 & .41 \\
\hline Affection & .84 & .85 & .76 & .57 & .74 & .46 \\
\hline Activation & .72 & .67 & .75 & .69 & .46 & .49 \\
\hline $\begin{array}{l}\text { Self-Brand } \\
\text { Connection }\end{array}$ & .84 & .74 & .86 & .86 & .75 & .45 \\
\hline $\begin{array}{l}\text { Brand Usage } \\
\text { Intent }\end{array}$ & .67 & .64 & .74 & .70 & .67 & .76 \\
\hline Mean & 4.56 & 3.96 & 4.12 & 4.46 & 4.03 & 4.48 \\
\hline Std. Dev. & 1.13 & 1.27 & 1.21 & 1.41 & 1.24 & 1.17 \\
\hline
\end{tabular}

Notes - Values below the diagonal are bivariate correlations between the constructs, bold diagonal elements represent the Average Variance Extracted (AVEs) for the relevant construct; Values above the diagonal represent squared correlations; Values below the diagonal represent correlations; $n=556$. 
Table 6: Overview - Hypothesis Testing Results (Study 4)

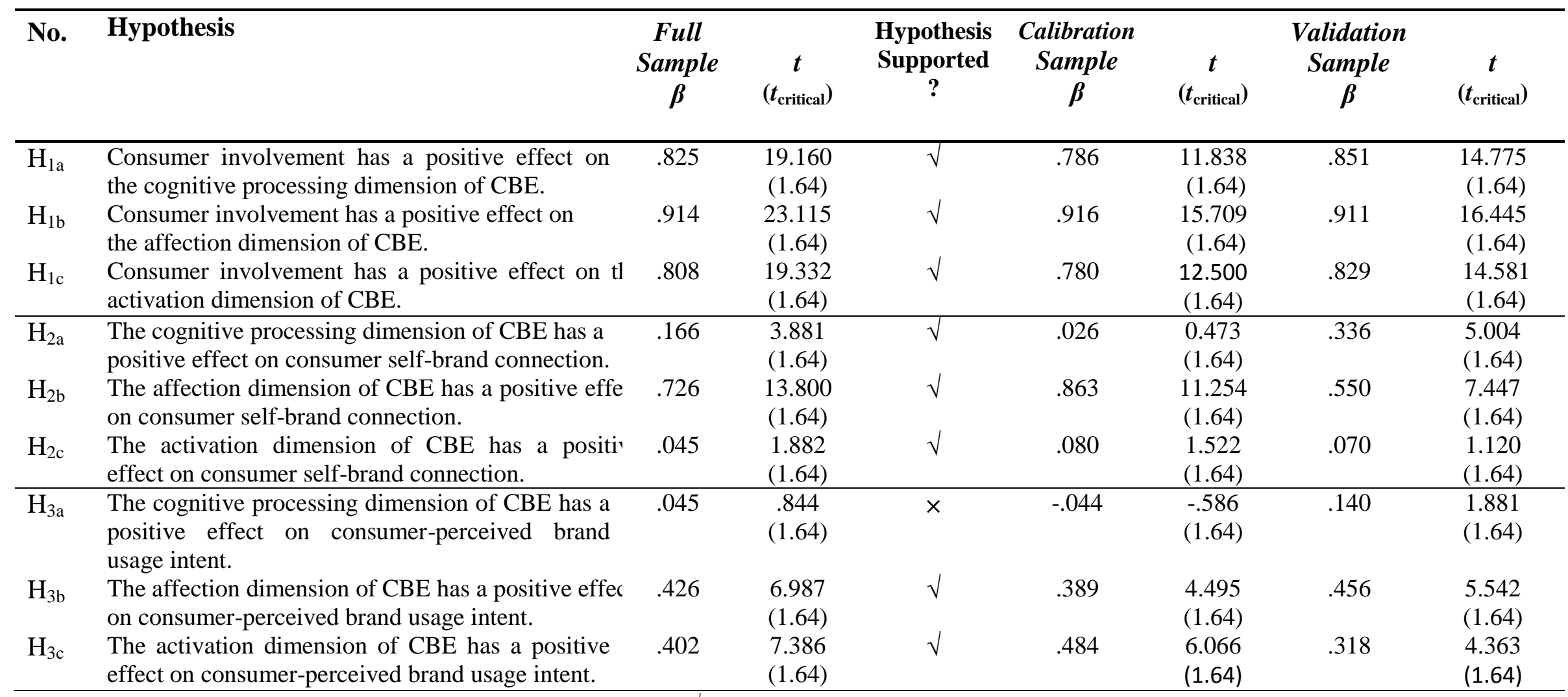

Notes - Full sample $n=556 ; p<.05 ; \beta$ : Standardized regression weight; $\sqrt{ }:$ Support for hypothesis attained; $\times$ : Lacking support for hypothesis; Calibration sample $n=278$; Validation sample $n=278$. 
Figure 1: Confirmatory Factor Analysis - Three-Factor CBE Scale (Study 3)

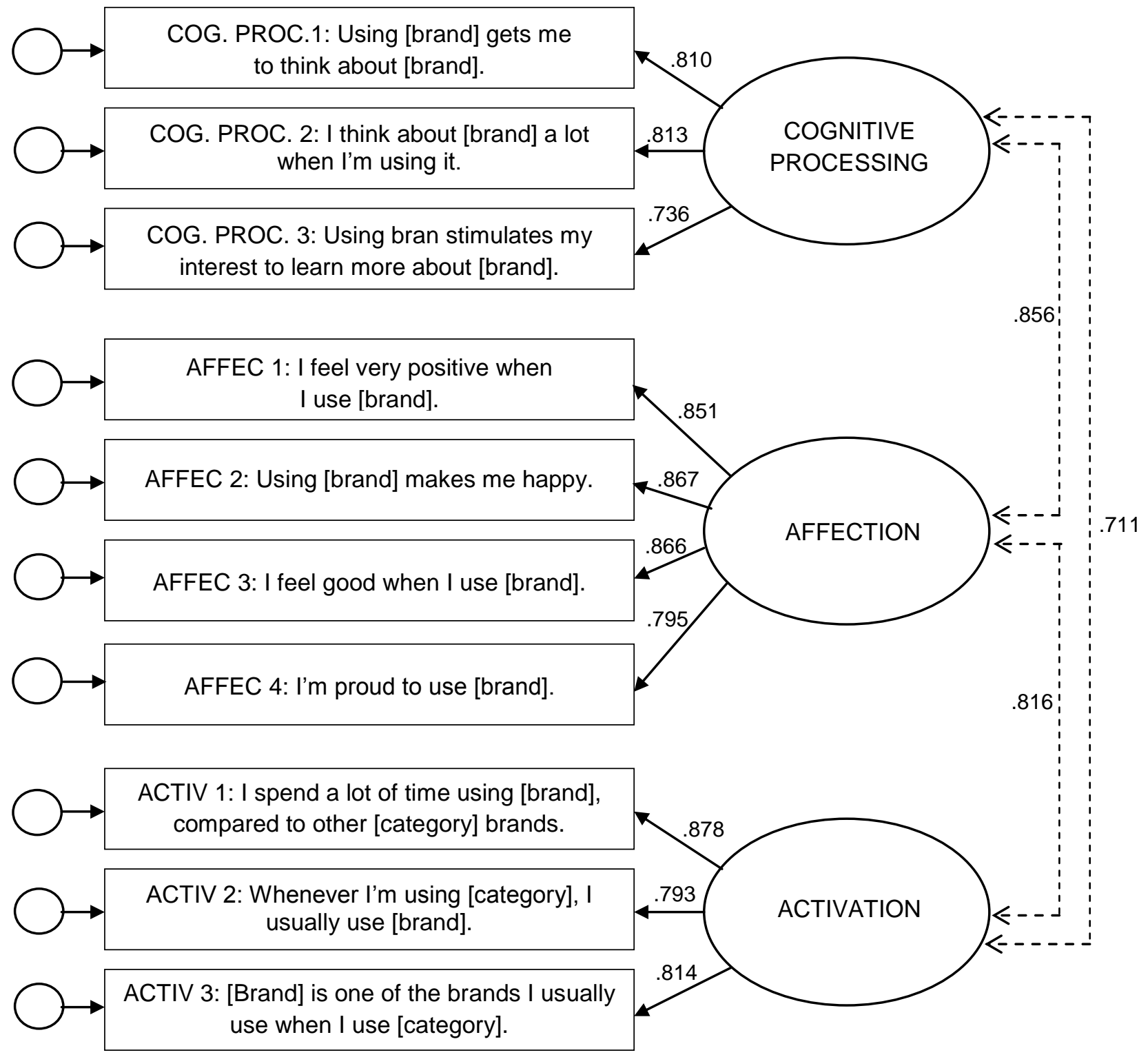

Notes - All standardized coefficients are significant $(p<.05)$ and appear above the associated path. Dotted lines represent correlations. 
Figure 2: Nomological Net of Selected CBE Conceptual Relationships (Study 4)

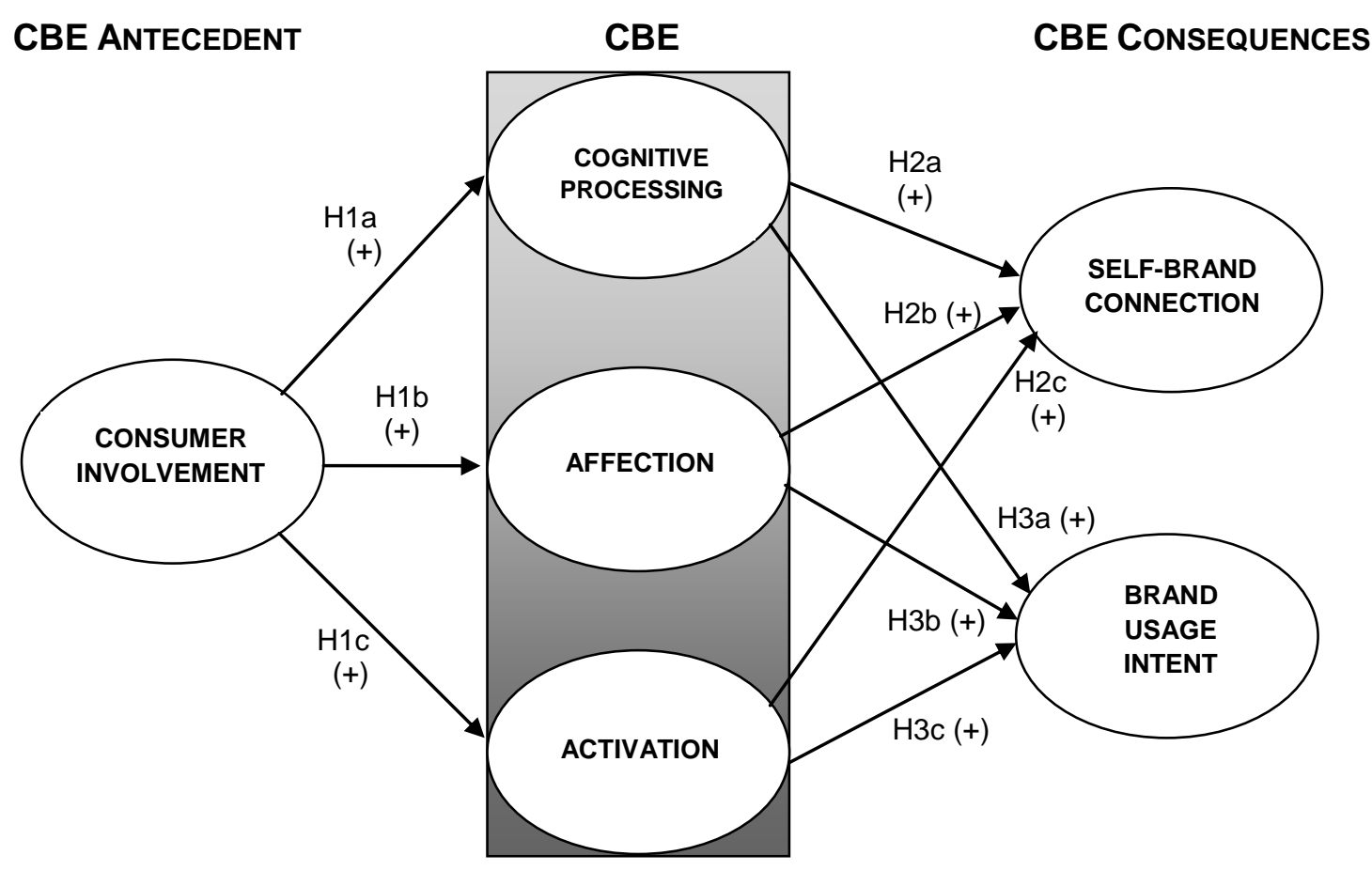

Figure 3: Alternative Model of Selected CBE Conceptual Relationships (Study 4)

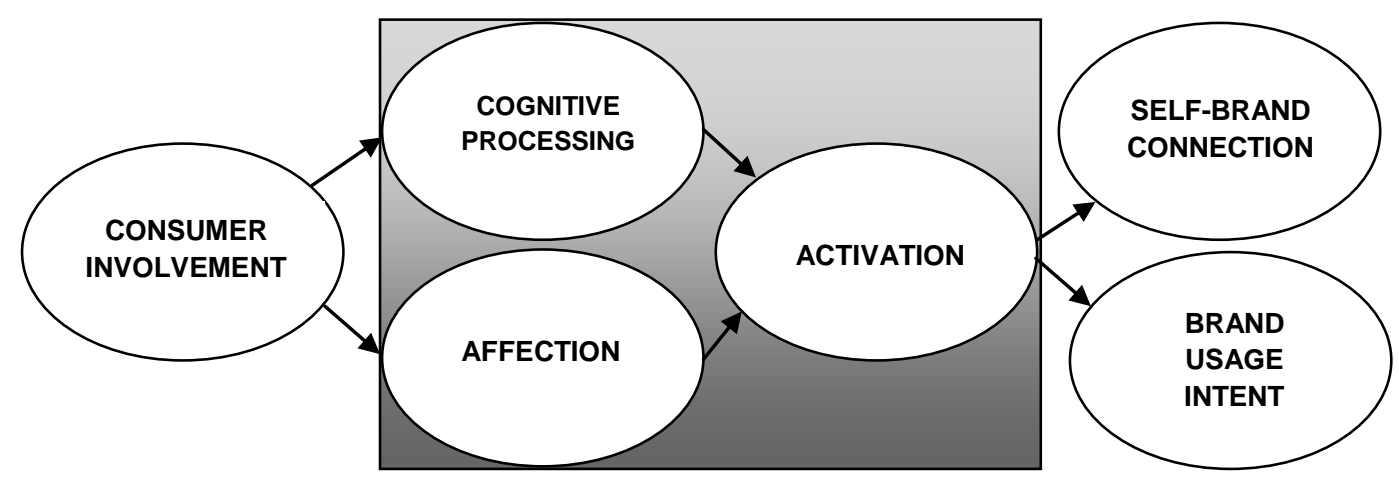




\section{Appendix: Overview - Selected CBE Conceptual Relationships (Study 4)}

\begin{tabular}{|c|c|c|c|}
\hline Concept & Definition & $\begin{array}{l}\text { Expected } \\
\text { Association } \\
\text { to CBE }\end{array}$ & Illustrative Respondent Statements \\
\hline \multirow[t]{2}{*}{$\begin{array}{l}\text { Consumer } \\
\text { involvement }\end{array}$} & \multirow[t]{2}{*}{$\begin{array}{l}\text { An individual's level of interest and } \\
\text { personal relevance in relation to a } \\
\text { focal object/decision in terms of } \\
\text { one's basic values, goals and self- } \\
\text { concept (Zaichkowsky 1985, 1994; } \\
\text { Mittal 1995). }\end{array}$} & \multirow[t]{2}{*}{ CBE antecedent } & $\begin{array}{l}\text { [I am interested in The Amazing Race] because in comparison to other TV } \\
\text { shows it's quite a mix of genres. You've got the competitive aspect that a } \\
\text { lot of reality television has. But you've also got the ,travel log } \\
\text { aspect...I'm quite interested in travel, so yeah, you're getting to see the } \\
\text { world from your chair. There's also the psychological side... Watching } \\
\text { how people perform under stress is in itself, very interesting. And then you } \\
\text { sit down and feel quite pleased, thinking "yeah, I've been there," in all } \\
\text { these places in the world, and then there's the ticking them off saying } \\
\text { "yeah, I've been there. That's why I'm interested in it; it's got me hooked } \\
\text { in. (Andrew, 39) }\end{array}$ \\
\hline & & & $\begin{array}{l}\text { With clothing, if you have a level of interest in clothing to begin with you } \\
\text { are going to be more aware and open to promotion or communication about } \\
\text { clothing brands... Some categories don't interest me at all, and other } \\
\text { categories interest me a lot. And then I must say; some product categories } \\
\text { just totally disinterest me. (Rachel, } 48 \text { ) }\end{array}$ \\
\hline \multirow[t]{2}{*}{$\begin{array}{l}\text { Self-brand } \\
\text { connection }\end{array}$} & \multirow[t]{2}{*}{$\begin{array}{l}\text { The extent to which individuals have } \\
\text { incorporated [a focal] brand(s) into } \\
\text { their self-concept (Escalas 2004). }\end{array}$} & \multirow[t]{2}{*}{$\begin{array}{l}\mathrm{CBE} \\
\text { consequence }\end{array}$} & $\begin{array}{l}\text { I guess it's that sense of 'I don't care' [about BP; i.e. non-engaging brand } \\
\text { selected]... I just don't care; it doesn't do anything for me. I don't feel any } \\
\text { sort of connection with the brand. [As opposed to The Amazing Race; i.e. } \\
\text { highly engaging brand selected], which I feel strongly towards, feel a } \\
\text { strong connection to. (Andrew, 39) }\end{array}$ \\
\hline & & & $\begin{array}{l}\text { I feel a connection to Mercs... [The brand] reflects who I am, or who I'd } \\
\text { like to be. [On the other hand, with Nivea (i.e. non-engaging brand } \\
\text { selected)], there's none of that psychological connection at all. (Eve, 65) }\end{array}$ \\
\hline \multirow[t]{2}{*}{$\begin{array}{l}\text { Brand usage } \\
\text { intent }\end{array}$} & \multirow{2}{*}{$\begin{array}{l}\text { Consumers' differential response } \\
\text { between a focal brand and an } \\
\text { unbranded product when both have } \\
\text { the same level of marketing stimuli } \\
\text { and product attributes (cf. 'Yoo and } \\
\text { Donthu's (2001) 'overall brand } \\
\text { equity'). }\end{array}$} & \multirow[t]{2}{*}{$\begin{array}{l}\mathrm{CBE} \\
\text { consequence }\end{array}$} & $\begin{array}{l}\text { I've known [Kinder Chocolate] since I was a child; It's just part of my life. } \\
\text { I talk about it with my family and friends. There are no real substitutes. } \\
\text { (Joan, 34) }\end{array}$ \\
\hline & & & $\begin{array}{l}\text { When I go to a restaurant and they have Pepsi I don't drink anything, if } \\
\text { they don't have Coke. So it's total abandonment of the other brands. (Rose, } \\
\text { 46) }\end{array}$ \\
\hline
\end{tabular}

